\title{
Protein S Protects Neurons from Excitotoxic Injury by Activating the TAM Receptor Tyro3-Phosphatidylinositol 3-Kinase-Akt Pathway through Its Sex Hormone-Binding Globulin-Like Region
}

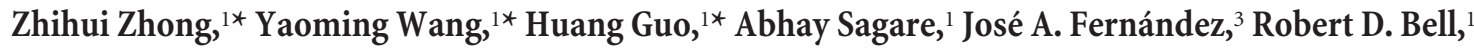 \\ Theresa M. Barrett, ${ }^{1}$ John H. Griffin, ${ }^{3}$ Robert S. Freeman, ${ }^{2}$ and Berislav V. Zlokovic ${ }^{1}$ \\ ${ }^{1}$ Center for Neurodegenerative and Vascular Brain Disorders, Department of Neurosurgery and Neurology, and ${ }^{2}$ Department of Pharmacology and \\ Physiology, University of Rochester Medical Center, Rochester, New York 14642, and ${ }^{3}$ Department of Molecular and Experimental Medicine, The Scripps \\ Research Institute, La Jolla, California 92037
}

The anticoagulant factor protein S (PS) protects neurons from hypoxic/ischemic injury. However, molecular mechanisms mediating PS protection in injured neurons remain unknown. Here, we show mouse recombinant PS protects dose-dependently mouse cortical neurons from excitotoxic NMDA-mediated neuritic bead formation and apoptosis by activating the phosphatidylinositol 3-kinase (PI3K)-Akt pathway $\left(\mathrm{EC}_{50}=26 \pm 4 \mathrm{nM}\right)$. PS stimulated phosphorylation of Bad and Mdm2, two downstream targets of Akt, which in neurons subjected to pathological overstimulation of NMDA receptors (NMDARs) increased the antiapoptotic Bcl-2 and Bcl- $\mathrm{X}_{\mathrm{L}}$ levels and reduced the proapoptotic $\mathrm{p} 53$ and Bax levels. Adenoviral transduction with a kinase-deficient Akt mutant (Ad.Akt ${ }^{K 179 A}$ ) resulted in loss of PS-mediated neuronal protection, Akt activation, and Bad and Mdm2 phosphorylation. Using the TAM receptors tyrosine kinases Tyro3-, Axl-, and Mer-deficient neurons, we showed that PS protected neurons lacking Axl and Mer, but not Tyro3, suggesting a requirement of Tyro3 for PS-mediated protection. Consistent with these results, PS dose-dependently phosphorylated Tyro3 on neurons $\left(\mathrm{EC}_{50}=\right.$ $25 \pm 3 \mathrm{nM}$ ). In an in vivo model of NMDA-induced excitotoxic lesions in the striatum, PS dose-dependently reduced the lesion volume in control mice $\left(\mathrm{EC}_{50}=22 \pm 2 \mathrm{nM}\right)$ and protected $\mathrm{Axl}^{-/-}$and $\mathrm{Mer}^{-1-}$ transgenic mice, but not Tyro3 ${ }^{-1-}$ transgenic mice. Using different structural PS analogs, we demonstrated that the C terminus sex hormone-binding globulin-like (SHBG) domain of PS is critical for neuronal protection in vitro and in vivo. Thus, our data show that PS protects neurons by activating the Tyro3-PI3K-Akt pathway via its SHGB domain, suggesting potentially a novel neuroprotective approach for acute brain injury and chronic neurodegenerative disorders associated with excessive activation of NMDARs.

\section{Introduction}

Protein S (PS) is a vitamin K-dependent anticoagulant plasma glycoprotein (Dahlbäck, 2007). It has a modular structure consisting of a $\gamma$-carboxyglutamic acid (Gla)-rich domain, a thrombin-sensitive region (TSR), four epidermal growth factorlike (EGF) domains, and a sex hormone-binding globulin-like region (SHBG) (Hafizi and Dahlbäck, 2006). Through its Gla domain, PS enhances activated protein C (APC)-dependent

Received Aug. 24, 2010; accepted Sept. 15, 2010.

This work was supported by National Institutes of Health Grant HL081528. We thank Dr. T. Hackeng (Maastricht University Medical Center, Maastricht, The Netherlands) for providing synthetic micro-protein S, Dr. S. Gandrille (University of Paris Rene Descartes, Paris, France) for providing recombinant rSHBG domain, Dr. G. Lemke (Salk Institute, La Jolla, (A) for providing Tyro3, Axl, and Mer transgenic mice and for his comments on this manuscript, and Dr. David Yule (University of Rochester, Rochester, NY) for lending us his equipment for the intracellular calcium imaging experiment.

*Z.Z., Y.W., and H.G. contributed equally to this work.

Correspondence should be addressed to Dr. Berislav V. Zlokovic, Center for Neurodegenerative and Vascular Brain Disorders, University of Rochester Medical Center, 601 Elmwood Avenue, Box 670, Rochester, NY 14642. E-mail: berislav_zlokovi@@urmc.rochester.edu.

DOI:10.1523/JNEUROSCI.4437-10.2010

Copyright $\odot 2010$ the authors $\quad$ 0270-6474/10/3015521-14\$15.00/0
(Saller et al., 2005) and APC-independent (Dahlbäck, 2007) anticoagulant activities and binds to negatively charged surfaces on the plasma membranes of apoptotic cells, which promotes phagocytosis by macrophages (Webb et al., 2002; Anderson et al., 2003; Uehara and Shacter, 2008). In vascular cells, PS exerts a potent mitogenic activity (Gasic et al., 1992; Benzakour et al., 1995; Fernández et al., 2009).

The growth arrest-specific gene-6 (gas6) protein shares with PS a unique arrangement of structural motifs and $43 \%$ amino acid homology (Dahlbäck, 2007). Gas6 activates the tyrosine kinase Tyro3 receptor in neurons (Prieto et al., 2007) and Axl receptor in oligodendroglia (Shankar et al., 2006) and vascular cells (Dahlbäck, 2007), resulting in cytoprotection. Previous in vitro studies have suggested that PS is a Tyro3 ligand (Stitt et al., 1995). Recent studies have demonstrated that PS interacts with the Mer receptor in the retina (Hall et al., 2005) and macrophages (Uehara and Shacter, 2008) mediating phagocytosis of photoreceptors and apoptotic cells, respectively. Another study suggested that PS is a biologically relevant ligand for both Mer and Tyro3 receptors in the retinal epithelium (Prasad et al., 2006). 
The Tyro3, Axl, and Mer (TAM) receptors are expressed in mammalian reproductive, immune, vascular, and nervous systems ( $\mathrm{Lu}$ et al., 1999; Prieto et al., 2000; Lu and Lemke, 2001; Lemke and Lu, 2003; Lemke et al., 2008). Relatively little is known about their role in brain except that Tyro3 single mutants develop seizures later in life (Lu et al., 1999), whereas triple mutants display apoptosis of the nervous tissue (Lu and Lemke, 2001). PS is expressed in brain (Jamison et al., 1995; Stitt et al., 1995) and in neural tumor cells (Phillips et al., 1993), cultured Schwann cells, and astrocytes (Stitt et al., 1995). Its expression in peripheral nerves is upregulated in response to injury (Stitt et al., 1995). This led to the hypothesis that PS provided neurotrophic support. Indeed, systemically administered PS confers neuronal protection during ischemic brain injury in mice and protects neurons from hypoxia/reoxygenation injury (Liu et al., 2003). Genetic knock-out of PS in mice causes embryonic lethal coagulopathy, thrombotic and ischemic injuries, intracerebral hemorrhages, and necrosis of the nervous tissue (Burstyn-Cohen et al., 2009; Saller et al., 2009). Brain damage in mice lacking PS could be attributable to ischemic/thrombotic injuries, but it may suggest that PS is needed during brain development for protection of the nervous tissue and/or vascular tissue. Whether PS can protect neurons from an acute injury and/or a neurodegenerative process by activating the cell survival pathways via TAM receptors is not known. To address this question, we studied PS activities using in vitro and in vivo models of neuronal injury caused by overstimulation of NMDA receptors (NMDARs) (Ayata et al., 1997; Du et al., 1997; Budd et al., 2000; Tenneti and Lipton, 2000; Okamoto et al., 2002; Guo et al., 2004, 2009a,b), and we identified PS domains that are critical for its neuronal protective activity.

\section{Materials and Methods}

Reagents. Full-length properly $\gamma$-carboxylated mouse recombinant PS was prepared and characterized as we described previously (Fernández et al., 2009). Human plasma-derived PS was purchased from Enzyme Research Laboratories. 2-Morpholin-4-yl-8-phenylchromen-4-one (LY294002) and 1,4-diamino-2,3-dicyano-1,4-bis(2-aminophenylthio)butadiene (U0126) were purchased from Cell Signaling Technology. Pifithrin- $\alpha$ (PFT- $\alpha)$ and caspase inhibitors, Ac-DEVD-CHO (caspase-3), z-IETD-fmk (caspase-8), and z-LEHD (caspase-9), were purchased from Sigma-Aldrich.

Neuronal cultures. Primary mouse cortical cells were isolated from mouse brain as described previously (Bonfoco et al., 1995; Guo et al., 2004). Briefly, cerebral cortex was dissected from fetal mice at exactly $16 \mathrm{~d}$ of gestation, treated with trypsin for $10 \mathrm{~min}$ at $37^{\circ} \mathrm{C}$, and dissociated by trituration. Dissociated cell suspensions were plated at $5 \times 10^{5}$ cells per well on 12-well tissue culture plates coated with poly-D-lysine, in serum-free Neurobasal medium plus B27 supplement. As we reported, astrocyte growth was suppressed between 0.3 and 1\% (Guo et al., 2004, $2009 a, b)$. Cultures were maintained in a humidified $5 \% \mathrm{CO}_{2}$ incubator at $37^{\circ} \mathrm{C}$ for $7 \mathrm{~d}$ in vitro (DIV7) or DIV21 to allow neurons to mature, as reported previously (Zhong et al., 1994; Lesuisse and Martin, 2002a,b).

NMDA injury model. Neuronal cultures were treated for $10 \mathrm{~min}$ with $300 \mu \mathrm{M}$ NMDA/5 $\mu \mathrm{M}$ glycine in $\mathrm{Mg}^{2+}$-free HBSS or HBSS alone (controls) followed by incubation with different concentrations of PS (i.e., from 5 to $100 \mathrm{~nm}$ ) for up to $24 \mathrm{~h}$ in serum-free Neurobasal medium plus B27 supplement. NMDA was purchased from Sigma-Aldrich.

Neuritic beading. Neuritic beading was assessed after incubation of NMDA-treated neurons with or without PS with Cell Tracker Green CMFDA (Invitrogen) for $30 \mathrm{~min}$ at $37^{\circ} \mathrm{C}$. Cells were fixed with $4 \%$ paraformaldehyde for $10 \mathrm{~min}$ followed by immunostaining with mouse monoclonal anti-bovine Map2 antibody, which cross-reacts with mouse Map2 (1:500; Millipore Bioscience Research Reagents). Alexa Fluor 568 donkey anti-mouse IgG (1:150; Invitrogen) was used as a secondary antibody. Images were scanned using a Zeiss 510 meta confocal microscope with a $488 \mathrm{~nm}$ argon laser to detect Cell Tracker Green and a $543 \mathrm{~nm}$ HeNe laser to detect Alexa Fluor 568 for Map2.
Mitochondrial membrane potential. We used a MitoTracker Red CMXROs (Invitrogen) to assess mitochondrial membrane potential. Neurons were incubated with $20 \mathrm{~nm}$ MitoTracker for $30 \mathrm{~min}$ at $37^{\circ} \mathrm{C}$. Cells were fixed with $4 \%$ paraformaldehyde for $10 \mathrm{~min}$. Images were scanned using a Zeiss 510 meta confocal microscope with a $543 \mathrm{~nm} \mathrm{HeNe}$ laser. Fluorescent signal intensity was quantified with MetaMorph software (Molecular Devices). Relative signal intensity was expressed as a percentage of control.

Intracellular ATP. We used a luminometric assay (APOSENSER Cell Viability Assay kit; BioVision) to assess intracellular ATP levels as described previously (Takeuchi et al., 2005). Briefly, the NMDA-treated neurons with or without PS were lysed and incubated with $100 \mu$ lof the Nuclear Releasing Reagent at room temperature for $5 \mathrm{~min}$. One microliter of ATP Monitoring Enzyme was added to the cell lysate for $1 \mathrm{~min}$, and then the samples were read in a luminometer (PerkinElmer). ATP concentration at each time point was calculated as a percentage of the nontreated control.

Neuronal viability. Neuronal viability was detected by WST-8 assay (Dojindo Molecular Technologies), which is a tetrazolium-based assay measuring the activity of the dehydrogenases in cells. The amount of the water-soluble formazan dye generated in the assay is directly proportional to the number of living cells. The cell survival rate was expressed as the viability percentage of the vehicle-treated cells.

Terminal deoxynucleotidyl transferase-mediated biotinylated UTP nick end labeling and Hoechst staining. Apoptosis was assessed by terminal deoxynucleotidyl transferase-mediated biotinylated UTP nick end labeling (TUNEL) (DeadEnd Fluorometric TUNEL System; Promega) and Hoechst (33,342; Invitrogen) staining using acetone-fixed cells. Images were observed using a Zeiss 510 meta confocal microscope. The number of apoptotic cells was expressed as the percentage of TUNEL-positive cells of the total number of nuclei determined by Hoechst staining.

Caspase- 9 , caspase- 8 , and caspase- 3 activities. The caspase- 9 , caspase- 8 , and caspase- 3 activities in neuronal cell lysates were determined using caspase-9, caspase-8, and caspase-3 Colormetric Assay kits (BioVision). Approximately $200 \mu \mathrm{g}$ of protein was incubated with DEVD-pNA (for caspase-3; $200 \mu \mathrm{M}$ ), IETD-pNA (for caspase-8; $200 \mu \mathrm{M}$ ) or LEHD-pNA (for caspase-9; $200 \mu \mathrm{M}$ ), and $10 \mathrm{~mm} \mathrm{DTT}$ at $37^{\circ} \mathrm{C}$ for $2 \mathrm{~h}$. Substrate hydrolysis was determined as absorbance change at $405 \mathrm{~nm}$ in a microplate reader. Enzymatic activity was expressed in arbitrary units (OD) per milligram of protein.

Immunoblotting analysis. Neuronal cells were lysed in Cell Lysis Buffer (Cell Signaling Technology) with protease inhibitors. Nuclear proteins were extracted using NE-PER nuclear extraction reagent (Pierce Biotechnology). Proteins $(20-50 \mu \mathrm{g})$ were analyzed by $4-15 \%$ Tris- $\mathrm{HCl}$ gel and transferred to nitrocellulose membranes $(0.45 \mu \mathrm{m}$; Bio-Rad Laboratories), which were then blocked by $5 \%$ nonfat milk or $5 \%$ bovine serum albumin (BSA) in TBS for $1 \mathrm{~h}$. The membranes were incubated overnight with primary antibodies diluted in 5\% nonfat milk or 5\% BSA in TBS, and then washed and incubated with a HRP-secondary antibody for $1 \mathrm{~h}$. Immunoreactivity was detected using the ECL detection system (GE Healthcare). We used the following primary antibodies: rabbit polyclonal anti-human apoptosis-inducing factor (AIF) antibody, which cross-reacts with mouse AIF (1:1000; Cell Signaling Technology); rabbit polyclonal anti-mouse phospho-Akt (Ser473) antibody (1:1000; Cell Signaling Technology); rabbit polyclonal anti-mouse Akt antibody (1:1000; Cell Signaling Technology); rabbit polyclonal anti-mouse phospho-Bad (Ser136) antibody (1:200; Cell Signaling Technology); rabbit polyclonal anti-mouse Bad antibody (1:1000; Cell Signaling Technology); mouse monoclonal anti-mouse Bcl-2 antibody (Santa Cruz Biotechnology); rabbit polyclonal anti-mouse $\mathrm{Bcl}-\mathrm{X}_{\mathrm{L}}$ antibody (Sigma-Aldrich); rabbit polyclonal anti-human phospho-Mdm2 (Ser166) antibody, which cross-reacts with mouse phospho-Mdm2 (Ser166) (1:1000; Cell Signaling Technology); rabbit polyclonal anti-human Mdm2 antibody, which cross-reacts with mouse Mdm2 (1:500; Abcam); rabbit polyclonal anti-human p53 antibody, which cross-reacts with mouse p53 (1:1000; Cell Signaling Technology); mouse monoclonal anti-mouse Bax (1:100; Santa Cruz Biotechnology); goat polyclonal anti-human $\beta$-actin antibody, which cross-reacts with mouse $\beta$-actin (1:1000; Santa Cruz Biotechnology); and sheep polyclonal anti-human histone 1 antibody, which cross-reacts with mouse histone 1 (1:1000; United 
States Biological). The relative abundance of proteins was determined by scanning densitometry and expressed relative to control groups that were arbitrarily assigned as 1 .

Intracellular $\mathrm{Ca}^{2+}$ measurement. The intracellular calcium $\left[\mathrm{Ca}^{2+}\right]_{\mathrm{i}}$ levels in mouse cortical neurons during NMDA stimulation were measured using a calcium-sensitive fluorescent dye fura-2 AM (Invitrogen) using a similar method as we previously described in brain endothelial cells (Dömötör et al., 2003). Briefly, neurons plated on poly-L-lysinecoated coverslips were incubated with $2 \mu \mathrm{M}$ fura-2 AM for $20 \mathrm{~min}$ in $\mathrm{Mg}^{2+}$-free HBSS at room temperature, and then rinsed and incubated for $30 \mathrm{~min}$ at $37^{\circ} \mathrm{C}$ in $\mathrm{Mg}^{2+}$-free HBSS. The coverslips were transferred to a Warner RC-25F perfusion chamber fitted to a stage of an inverted Nikon Eclipse Ti microscope and perfused with $\mathrm{Mg}^{2+}$-free HBSS for 5 min. All reagents were infused via a multitube perfusion system. $\left[\mathrm{Ca}^{2+}\right]_{\mathrm{i}}$ was measured by digital image fluorescence microscopy (objective, Fluor 40/1.3; Nikon) using Vision 4.0 software from TILL Photonics. Excitation wavelengths were 340 and $380 \mathrm{~nm}$ generated by a polychromator illumination system (TILL Photonics). Fluorescence emission was collected at $510 \mathrm{~nm}$. A fluorescence ratio image $(340 / 380 \mathrm{~nm})$ was acquired every $2 \mathrm{~s}$ with a CCD camera (TILL Photonics) before, during, and after HBSS infusion with vehicle, $100 \mathrm{~nm}$ PS, $300 \mu \mathrm{M}$ NMDA, or $300 \mu \mathrm{M}$ NMDA with $100 \mathrm{~nm}$ PS. The images were analyzed with the NIH ImageJ software integrated density measurement tool. Three to eight individual cells in the image field were analyzed per coverslip and averaged. Six coverslips were analyzed per group. Using the Fura-2 Calcium Imaging Calibration kit (Invitrogen), a standard curve was generated to convert the fura- 2 fluorescence values obtained from experimental samples into free $\mathrm{Ca}^{2+}$ concentrations using radiometric analysis according to the manufacturer's instructions using the following formula: $\left[\mathrm{Ca}^{2+}\right]_{\mathrm{i}}=$ $K_{\mathrm{d}} \times\left[\left(R-R_{\min }\right) /\left(R_{\max }-R\right)\right] \times\left(F_{\text {max }}^{380} / F_{\text {min }}^{380}\right)$, where $R$ is the ratio of $510 \mathrm{~nm}$ emission intensity at $340-380 \mathrm{~nm}$ excitation; $R_{\min }$ is the ratio at zero free $\mathrm{Ca}^{2+} ; R_{\max }$ is the ratio at saturating $\mathrm{Ca}^{2+}(39 \mu \mathrm{M}) ; F^{380}{ }_{\max }$ is the fluorescent intensity using $380 \mathrm{~nm}$ excitation at zero free $\mathrm{Ca}^{2+}$; and $F^{380}{ }_{\text {min }}$ is the fluorescent intensity using $380 \mathrm{~nm}$ excitation at saturating free $\mathrm{Ca}^{2+} \cdot K_{\mathrm{d}}$ was calculated from the $x$-intercept of the plot of $\left[\mathrm{Ca}^{2+}\right]$ free on the $x$-axis versus $\left[\left(R-R_{\min }\right) /\left(R_{\max }-R\right)\right] \times\left(F^{380}{ }_{\text {max }} / F^{380}{ }_{\text {min }}\right)$ on $y$-axis acquired from the calibration kit. The free $\mathrm{Ca}^{2+}$ for experimental samples was then calculated from the corresponding $R$ values. Calibrated data were pooled and plotted as means \pm SEM.

Glutamate release. Glutamate release from cultured cortical neurons was measured using an Amplex Red glutamic acid/glutamate oxidate assay kit (Invitrogen) (Nakatsu et al., 2006; Kajimoto et al., 2007). Cortical neurons were maintained for $7 \mathrm{~d}$ in vitro and treated with NMDA with or without PS. The medium was collected and analyzed for glutamate content according to the manufacturer's instructions. The resulting increase in fluorescence was measured at an excitation of $540 \mathrm{~nm}$ and emission of $590 \mathrm{~nm}$ using a fluorescence microplate reader (PerkinElmer).

Akt kinase activity assay. To assess Akt kinase activity, cells were washed twice in cold PBS, and lysed in Cell Lysis Buffer (supplied in the Akt Kinase Activity kit; Cell Signaling Technology) with protease inhibitors. Immunoprecipitation was performed for $18 \mathrm{~h}$ using the immobilized anti-Akt1G1 mAb (supplied with the kit) cross-linked to agarose. Immunoprecipitates were washed three times with lysis buffer and twice with Akt kinase buffer (supplied with the kit). Kinase assays were performed for $30 \mathrm{~min}$ at $30^{\circ} \mathrm{C}$ under continuous agitation in kinase buffer containing $200 \mu \mathrm{m}$ ATP, $1 \mu \mathrm{g}$ of glycogen synthase kinase-3 (GSK-3) fusion protein (supplied with the kit), according to the manufacturer's instructions for the nonradioactive Akt kinase assay. Samples were analyzed by Western blotting using phospho-GSK-3 $\alpha / \beta$ (Ser21/9) antibody (supplied with the kit) as the primary antibody and a HRP-conjugated goat anti-rabbit IgG antibody (Dako) as the secondary antibody.

Ad.Akt ${ }^{K 179 A}$ construct. The kinase-inactive Akt ${ }^{\mathrm{K} 179 \mathrm{~A}}$ construct (Crowder and Freeman, 1998) was cloned into a green fluorescent protein (GFP)containing adenoviral vector using AdEasy XL system (Stratagene). The adenoviral product containing Akt ${ }^{\mathrm{K} 179 \mathrm{~A}}$ was proliferated in HEK $293 \mathrm{~A}$ cells purchased from American Type Culture Collection and purified using ViraKit (Virapur). Cortical neurons were transduced with adenoviral constructs (200 multiplicities of infection) $24 \mathrm{~h}$ before studies. The transduction effi- ciency was determined by GFP signal and immunoblotting analysis of total Akt.

Silencing through RNA interference. Small interfering RNA (siRNA) targeting mouse $\mathrm{Mdm} 2$, Bad, sphingosine 1-phosphate receptor 1 $\left(\mathrm{S}_{\mathrm{P}} \mathrm{P}_{1}\right)$, Tyro3, and negative control siRNAs were purchased from Invitrogen. siRNAs were delivered to the mouse cortical neurons by using Lipofectamine provided by Invitrogen. After $48 \mathrm{~h}$ of transfection, neurons were verified for target gene knockdown by immunoblotting analysis and subjected to NMDA treatment. The following pooled sequences of siRNA oligonucleotides were used for targeted gene knockdown: Bad, GACGACGUGUCUCAUGGCAGAGUUU and AAACUCUGCCAUGAGACACGUCGUC; Mdm2, AgGCUUGGAUGUGCCUGAUGGCAAA and UUUGCCAUCAGGCACAUCCAAGCCU; S1P 1 , GGCAUGGAAUUUAGCCGCAGCAAAU and AUUUGCUGCGGCUAAAUUCCAUGCC; Tyro3, GCAGACGCCAUAUGCUGGCAUUGAA and UUCAAUGCCAGCAUAUGGCGUCUGC.

$\mathrm{Bad} / \mathrm{Bcl}-2$ and $\mathrm{Bad} / \mathrm{Bcl}-\mathrm{X}_{L}$ complexes. Neurons were lysed in the Immunoprecipitation Kit Lysis Buffer (Roche), sonicated at $4^{\circ} \mathrm{C}$ for $30 \mathrm{~min}$, and centrifuged at $20,000 \times g$ for $20 \mathrm{~min}$. The supernatants were incubated for $2 \mathrm{~h}$ at $4^{\circ} \mathrm{C}$ with a rabbit polyclonal anti-Bad antibody (Cell Signaling Technology) to immunoprecipitate Bad and its complexes. Nonimmune IgG was used as a negative control. Protein A beads were added to the mixture and incubated overnight at $4^{\circ} \mathrm{C}$. Immunoprecipitated proteins were analyzed by $4-15 \%$ Tris- $\mathrm{HCl}$ gel electrophoresis. To assess the presence of $\mathrm{Bad} / \mathrm{Bcl}-2$ and $\mathrm{Bad} / \mathrm{Bcl}-\mathrm{X}_{\mathrm{L}}$ complexes, a mouse monoclonal Bcl-2 antibody (Santa Cruz Biotechnology), a rabbit polyclonal Bcl- $\mathrm{X}_{\mathrm{L}}$ antibody (Sigma-Aldrich), and a rabbit polyclonal Bad antibody (Cell Signaling Technology) were used for immunoblotting. Donkey anti-goat or donkey anti-rabbit HRP-conjugated antibodies (Santa Cruz Biotechnology) were used as secondary antibodies.

Immunostaining for Tyro3, Axl, and Mer. Cultured neurons were fixed with $4 \%$ paraformaldehyde for $10 \mathrm{~min}$ and incubated overnight at $4{ }^{\circ} \mathrm{C}$ with goat polyclonal anti-mouse Tyro3 (1:50; R\&D Systems), goat polyclonal anti-mouse Axl (1:50; R\&D Systems), goat polyclonal anti-mouse Mer (1:50; R\&D Systems), and mouse monoclonal anti-bovine Map2 (1:500; Millipore Bioscience Research Reagents) antibodies. The following day, the sections were incubated with fluorescently conjugated secondary antibodies diluted 1:200 in PBS as follows: Alexa Fluor 488conjugated donkey anti-goat IgG (1:150; Invitrogen) to detect Tyro3, Axl, or Mer, and Alexa Fluor 568-conjugated goat anti-mouse IgG (1: 150; Invitrogen) to detect Map2. Images were obtained using a Zeiss 510 meta confocal microscope. A $488 \mathrm{~nm}$ argon laser to excite Alexa Fluor 488 and the emission was collected through a $500-550$ bp filter, and a 543 $\mathrm{nm}$ HeNe laser was used to excite Alexa Fluor 568, and the emission was collected through a 560-615 bp filter.

Immunoblotting for Tyro3, Axl, and Mer. Thirty micrograms of neuronal lysate protein was subjected to $4-12 \%$ NuPAGE Bis-Tris SDS-PAGE (Invitrogen) gel electrophoresis and transferred to nitrocellulose membranes (Bio-Rad). Membranes were blocked with $5 \%$ nonfat milk in TBST for $1 \mathrm{~h}$ and incubated overnight with the following primary antibodies: Tyro3 (1:100; R\&D Systems), Axl (1:100; R\&D Systems), and Mer (1:100; R\&D Systems). The membranes were washed and incubated with a HRP-conjugated secondary antibody for $1 \mathrm{~h}$. Immunoreactivity was detected using SuperSignal West Pico chemiluminescent substrate (Thermo Fisher Scientific).

TAM mutants. Male Tyro3 ${ }^{-1-}, \mathrm{Axl}^{-1-}, \mathrm{Mer}^{-1-}$ transgenic mice were originally on C57BL/6-129 background (Lu et al., 1999; Lu and Lemke, 2001). These mice were backcrossed for several generations (more than eight) to attain the $\mathrm{C} 57 \mathrm{BL} / 6$ background and were generated by null-null breeding. The C57BL/6 mice were used as wild-type (wt) controls for the TAM-null mice, as described in a previous publication (Rothlin et al., 2007) and on The Jackson Laboratory website (http://jaxmice.jax.org/ strain/007937.html). Mice were studied at 2-3 months of age. The breeding pairs were provided by Dr. G. Lemke (Salk Institute, La Jolla, CA).

Tyro3 tyrosine phosphorylation. Neurons were lysed with radioimmunoprecipitation assay buffer (50 mM Tris, $\mathrm{pH} 8.0,150 \mathrm{~mm} \mathrm{NaCI}, 0.1 \%$ SDS, $1.0 \%$ NP-40, $0.5 \%$ sodium deoxycholate, and Roche protease inhibitor mixture) and incubated with a rabbit anti-phospho-tyrosine antibody (Abcam) or a control nonimmune IgG (Sigma-Aldrich) overnight at $4^{\circ} \mathrm{C}$. The samples 
were then immunoprecipitated using a protein $G$ immunoprecipitation kit (Roche) followed by SDS-PAGE separation and transfer onto nitrocellulose membranes (Millipore). After blocking nonspecific sites with $5 \%$ milk, the membranes were incubated with a rat monoclonal antimouse Tyro3 antibody (R\&D Systems) or a rabbit anti-mouse vascular endothelial growth factor receptor 2 (VEGFR2) antibody (Millipore) for a loading control. After incubation with an HRPconjugated donkey-anti-goat secondary antibody (Santa Cruz Biotechnology), the immunoreactivity was detected using the SuperSignal West Pico chemiluminescent substrate (Thermo Fisher Scientific). Cells were treated with mouse PS for 15 min.

PS variants. The thrombin-cleaved PS was prepared as described previously (Heeb and Griffin, 2002). Briefly, human plasma-derived PS $(1.8 \mu \mathrm{M})$ was incubated with immobilized thrombin $(50 \mathrm{U} / \mathrm{ml})$ and sampled at different time points ( $20 \mathrm{~min}$ to $24 \mathrm{~h}$ ). Aliquots were resolved in SDS-PAGE under reducing or nonreducing conditions, and applied to silver staining (silver staining kit; GE Healthcare). The reducing gel demonstrates rapid cleavage on Arg49, and nonreducing gel demonstrates slow cleavage on Arg70.

Synthetic human micro-PS containing the Gla domain, the TSR region, and the first EGF domain and exhibiting 30\% of PS anticoagulant APC-cofactor activity was prepared as described previously (Hackeng et al., 2000).

The human recombinant rSHBG-like module was a gift from Dr. Sophie Gandrille (University of Paris, Paris, France). As reported, the recombinant rSHBG module of human PS does not exhibit anticoagulant APC-cofactor activity but appears to retain its native conformation as in full-length PS (Saposnik et al., 2003).

Activated partial thromboplastin time assay. The anticoagulant activities of PS variants were determined by an activated partial thromboplastin time (aPTT) assay, as described previously (Heeb and Griffin, 2002), using a ST coagulameter (Diagnostica Stago). The anticoagulant APC-cofactor activity of PS variants was expressed as a percentage of wild-type, fulllength PS whose activity was taken as $100 \%$.

NMDA-induced in vivo brain lesion. We used an NMDA model of excitotoxic lesions in the mouse brain in vivo, as described previously (Ayata et al., 1997; Guo et al., 2004, 2009b). Male C57BL/6 control mice and $\mathrm{Tyro3}^{-1-}, \mathrm{Axl}^{-1-}$, and $\mathrm{Mer}^{-1-}$ mutants weighing 26-30 g were used throughout the study. Mice were anesthetized with $1.5 \%$ isoflurane (in $70 \%$ nitric oxide and $30 \%$ oxygen). Animals received microinfusions into the right striatum $(0.5 \mathrm{~mm}$ anterior, $2.5 \mathrm{~mm}$ lateral, $3.2 \mathrm{~mm}$ ventral to the bregma) of either vehicle, NMDA (20 nmol in $0.3 \mu$ l of PBS, pH 7.4) or NMDA and PS (0.002, 0.02, and $0.2 \mu \mathrm{g}$ in $0.3 \mu \mathrm{l}$ of PBS) or NMDA and Ac-DEVD-CHO $(240 \mu \mathrm{g}$ in $0.3 \mu \mathrm{l}$ of PBS), z-IETD-fmk (60 $\mu \mathrm{g}$ in $0.3 \mu \mathrm{l}$ of PBS), z-LEHD (240 $\mu \mathrm{g}$ in $0.3 \mu \mathrm{l}$ of PBS), or PFT- $\alpha$ (20 nmol in $0.3 \mu \mathrm{l}$ of PBS). The solutions were infused over 2 min using a microinjection system (World Precision Instruments). In wt mice, the final concentrations of PS in brain tissue at the site of injection after $2 \mathrm{~min}$ infusion ranged from 2.6 to $260 \mathrm{nmol} / \mathrm{L}$ as determined from a dilution factor of Evans blue albumin infused simultaneously with PS in a separate series of experiments, as reported previously (Kakee et al., 1996) (see below). In TAM mutants and control wild-type mice, the concentration of PS and PS variants at the site of
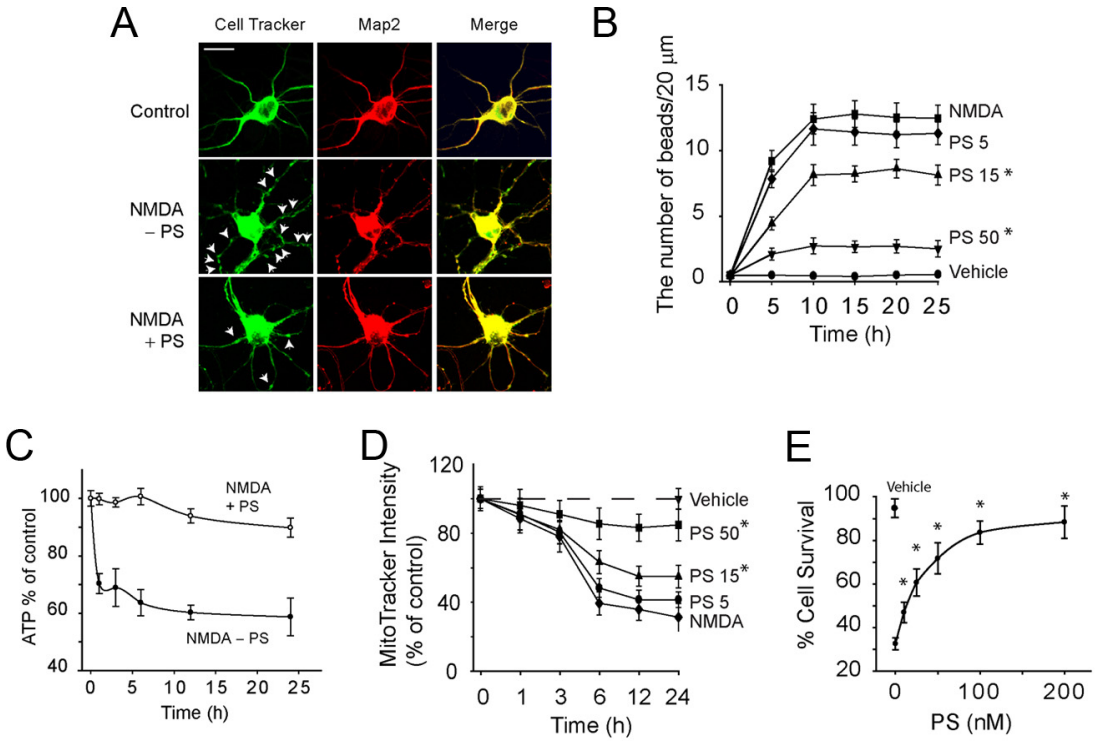
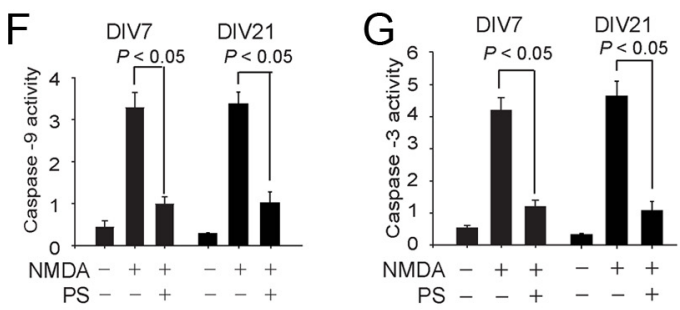

$\mathrm{H}$

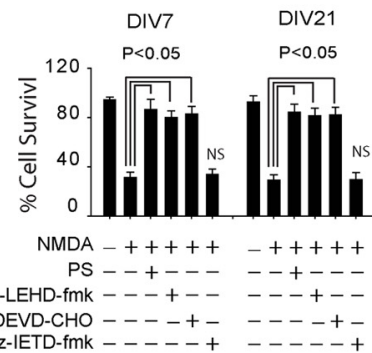

$\begin{aligned} \text { AC-DEVD-CHO }----+- & ----+- \\ \text { Z-IETD-fmk }-----+ & -----+\end{aligned}$

DIV7
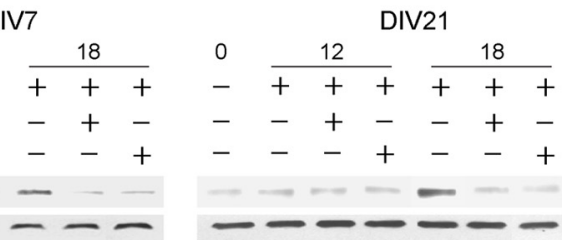

Figure 1. PS protects mouse neurons against NMDA-induced excitotoxic injury. $\boldsymbol{A}$, Cell Tracker (green) and cytoskeletal protein Map2 (red) in mouse cortical neurons $3 \mathrm{~h}$ after NMDA with and without PS. Scale bar, $10 \mu \mathrm{m}$. $\boldsymbol{B}$, The number of beads per neurite length in cortica (Dependent survival of cortical neurons after NMDA. $\boldsymbol{F}, \mathbf{G}$, Caspase-9 $(\boldsymbol{F})$ and caspase-3 $(\boldsymbol{G})$ activities in mouse cortical neurons (DIV7 (D) $9 \mathrm{~h}$ after NMDA with and without PS. $\boldsymbol{H}$, Survival of mouse cortical neurons (DIV7 and DIV21) 24 $\mathrm{h}$ after NMDA with and without 21) 12 and $18 \mathrm{~h}$ after NMDA with or without PS or Ac-DEVD-CHO $(50 \mu \mathrm{m})$. Caspase inhibitors were added to the cultures $1 \mathrm{~h}$ before NMDA treatment. Values are mean $\pm \mathrm{SEM} ; n=3-6$ independent cultures. In all studies, murine PS was used at $100 \mathrm{~nm}$ unless otherwise specified. In $\boldsymbol{A}-\boldsymbol{E}$, cortical neurons at DIV7 were used.

injection after $2 \mathrm{~min}$ infusion was $260 \mathrm{~nm}$. Animals were killed $48 \mathrm{~h}$ later. Brains were quickly removed, frozen on dry ice, and stored at $-80^{\circ} \mathrm{C}$ until processing. Thirty-micrometer-thick coronal sections were prepared using a cryostat. Every fifth section $1 \mathrm{~mm}$ anterior and posterior to the site of injection was stained with cresyl violet. The lesion area was identified by the loss of staining as reported previously (Ayata et al., 1997; Guo et al., 2004, 2009b). The lesion areas were determined using NIH ImageJ software and integrated to obtain the volume of injury. All studies were performed in a blind fashion. We studied four to six mice per group. All procedures were approved by the Institutional Animal Care and Use Committee at the University of Rochester using National Institutes of Health guidelines.

Determination of the final concentration of PS and PS variants in brain tissue. The final concentrations of PS and PS variants in brain tissue were determined from the dilution factor of the injected proteins into the brain interstitial fluid (ISF), as reported previously (Kakee et al., 1996). Evans blue, a dye that avidly binds albumin $(67 \mathrm{kDa})$, was used to deter- 
A

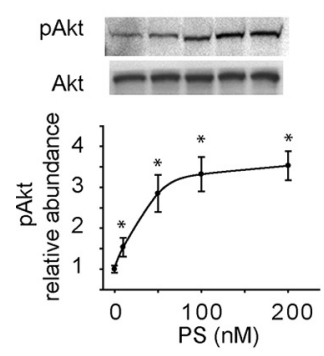

B

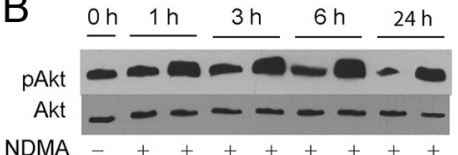

NDMA PS

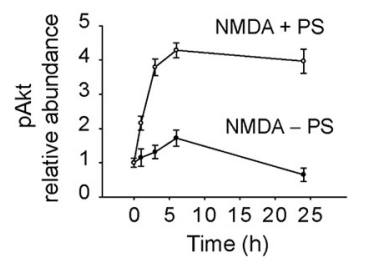

D

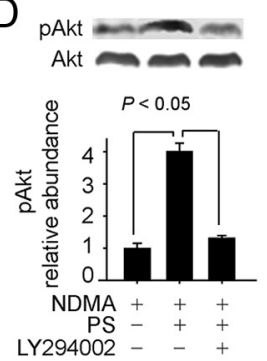

$\mathrm{E}$

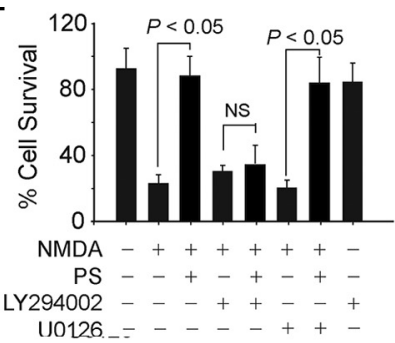

$\mathrm{F}$

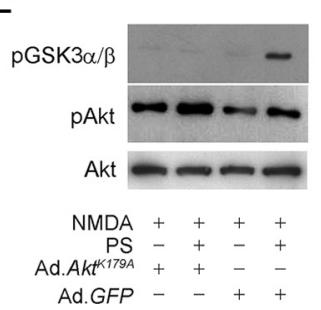

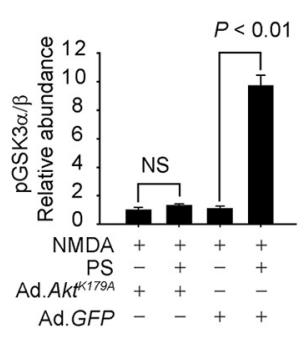

G

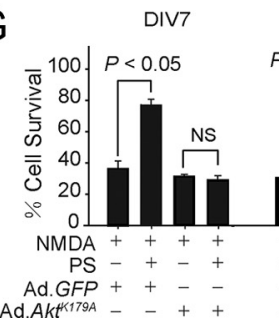

Figure 2. PS protects NMDA-treated mouse neurons via activation of PI3K/Akt antiapoptotic pathway. $A$, PS dose-dependently (5-200 nM) mediates Akt phosphorylation (pAkt, Ser473) in mouse cortical neurons $1 \mathrm{~h}$ after NMDA. Graph, pAkt relative abundance normalized to total Akt. ${ }^{*} p<0.05$, PS compared with untreated NMDA controls. B, Akt phosphorylation (pAkt, Ser473) in mouse cortical neurons 1-24 $\mathrm{h}$ after NMDA with and without PS. Graph, pAkt signal normalized by total Akt. C, Akt activity determined by a GSK-3 $\alpha / \beta$ phosphorylation-based assay $1 \mathrm{~h}$ after NMDA in the absence and presence of PS. pAkt and total Akt levels were determined by immunoblotting analysis from the same samples used in Akt activity assay. Graph, Relative abundance of pGSK-3 $\alpha / \beta$ normalized by total Akt. D, Akt phosphorylation (pAkt, Ser 473) and total Akt levels in mouse cortical neurons $24 \mathrm{~h}$ after NMDA with or without PS or the PI3K inhibitor LY294002 $(50 \mu \mathrm{M})$. E, Survival of mouse cortical neurons $24 \mathrm{~h}$ after NMDA with and without PS in the presence and absence of LY294002 (50 $\mu \mathrm{M})$ or U0126 (10 $\mu \mathrm{M})$. LY294002 and U0126 were added to the culture 30 min before NMDA treatment. $\boldsymbol{F}$, Akt kinase activity in neurons transduced with kinase-deficient Ad. $A k t^{K 179 A}$ mutant or control Ad.GFP determined $1 \mathrm{~h}$ after NMDA with and without PS by using a GSK-3 $\alpha / \beta$ phosphorylation-based Akt activity assay. Graph, Relative abundance of pGSK-3 $\alpha / \beta$ normalized by total Akt. pAkt and total Akt levels are also shown. G, Survival of DIV7 and DIV21 mouse cortical neurons transduced with Ad. $A k t^{K 179 A}$ mutant or control Ad.GFP $24 \mathrm{~h}$ after NMDA with and without PS. Values are mean \pm SEM from three to six independent cultures. In all studies, DIV7 cortical neurons and murine PS at $100 \mathrm{~nm}$ were used unless otherwise specified.

mine the dilution factor from its diffusion volume within the brain ISF. The molecular weight of the Evans blue-albumin complex (68 kDa) is similar to that of PS ( $69 \mathrm{kDa})$. In brief, Evans blue $(4 \mathrm{mg} / \mathrm{ml})$ was incubated with the equimolar concentration of BSA in artificial CSF for $3 \mathrm{~h}$ at room temperature, filtered using $0.2 \mu \mathrm{m}$ filter and $0.3 \mu \mathrm{l}$ microinjected into the striatum over $2 \mathrm{~min}$, as in the NMDA-induced in vivo brain lesion experiments. After $30 \mathrm{~min}$, the brain was rapidly removed, placed in a brain matrix on an ice-cold dish, and cut into 1-mm-thick sections. The Evans blue-stained areas of each section were carefully removed, using a dissecting microscope, and weighed. The diffusion volume of Evans blue was estimated assuming a brain-specific density of 1 , as reported previously (Kakee et al., 1996). The dilution factor $(32.8 \pm 3.8$; $n=3$ ) was determined by dividing the diffusion volume by the injected volume (data not shown). The final concentration of PS and PS variants in the brain tissue was determined by dividing their injected concentrations by the dilution factor (data not shown).
C
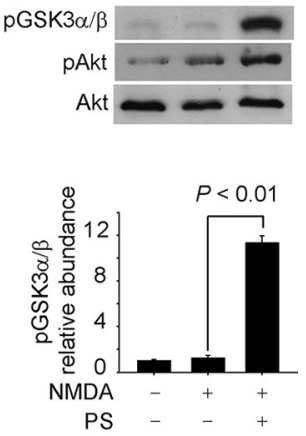

DIV21
$P<0.05$

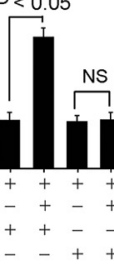

Caspase-3 activity in the mouse striatum. Mouse striatum ipsilateral to NMDA lesion was collected $24 \mathrm{~h}$ after NMDA (20 nmol in 0.3 $\mu \mathrm{l}$ of PBS, $\mathrm{pH} 7.4)$ or NMDA and PS $(0.2 \mu \mathrm{g}$ in $0.3 \mu \mathrm{l}$ of PBS) microinfusions. The tissue was lysed using Cell Lysis Buffer (Cell Signaling Technology) with protease inhibitors. Caspase-3 activity was determined using caspase- 3 Colorimetric Assay kit (BioVision), as described above.

Immunoblotting analysis in the mouse striatum. Mouse striatum ipsilateral to NMDA lesion was collected $24 \mathrm{~h}$ after NMDA (20 nnmol in $0.3 \mu$ l of PBS, pH 7.4) or NMDA and PS ( 0.2 $\mu \mathrm{g}$ in $0.3 \mu \mathrm{l}$ of PBS) microinfusions. Tissue samples were snap-frozen in liquid nitrogen and homogenized using Cell Lysis Buffer (Cell Signaling Technology) with protease inhibitors.

Nuclear proteins were extracted using NEPER nuclear extraction reagents (Pierce Biotechnology). Proteins $(50 \mu \mathrm{g})$ were analyzed by immunoblotting as described above. We used the following primary antibodies: rabbit polyclonal anti-human phospho-Mdm2 (Ser166) antibody, which cross-reacts with mouse phospho-Mdm2 (Ser166) (1:1000; Cell Signaling Technology); rabbit polyclonal anti-human p53 antibody, which cross-reacts with mouse p53 (1:1000; Cell Signaling Technology); mouse monoclonal antimouse Bax (1:100; Santa Cruz Biotechnology); rabbit polyclonal anti-mouse phospho-Bad (Ser136) antibody (1:200; Cell Signaling Technology); goat polyclonal anti-human $\beta$-actin antibody, which cross-reacts with mouse $\beta$-actin ( 1 1000; Santa Cruz Biotechnology); sheep polyclonal anti-human histone 1 antibody, which cross-reacts with mouse histone 1 (1:1000; United States Biological).

Statistical analysis. We used S-plus 7.0 for statistical calculations. Data were presented as mean \pm SEM. One-way or two-way ANOVA followed by Tukey's post hoc test was used to determine statistically significant differences. A value of $p<0.05$ was considered statistically significant.

\section{Results}

\section{PS protects neurons from excitotoxic NMDA-mediated injury via Akt signaling}

First, we studied whether exogenous mouse PS can protect cultured neurons from NMDA-mediated injury. Overstimulation of glutaminergic NMDARs is a common mechanism of neuronal injury in several neurological disorders. For example, neuritic beading (focal bead-like swelling of dendrites and axons) through NMDARs signaling occurs after ischemia (Hori and Carpenter, 1994), in Alzheimer's disease (Tan et al., 2007; Woodhouse et al., 2009), and in other neurodegenerative conditions (Takeuchi et al., 2005). Our data show that addition of recombinant full-length properly $\gamma$-carboxylated mouse recombinant murine PS (Fernández et al., 2009) dosedependently reduced neuritic bead formation after NMDA treatment by as much as $\sim 80 \%$ (Fig. $1 A, B$ ) with a half-maximal effective concentration $\left(\mathrm{EC}_{50}\right)$ of $\sim 25 \mathrm{nM}$; the effect plateaued between 50 and $250 \mathrm{~nm}$ PS (data not shown). As seen previously (Takeuchi et al., 2005), beads colocalized with the cytoskeletal proteins Map2 (Fig. 1A) and tubulin (data not shown). PS also 
blocked a rapid drop in intracellular ATP (Fig. 1C) and mitochondrial membrane potential (Fig. 1D) that accompanied bead appearance.

Overstimulation of NMDARs can lead to neuronal death (Guo et al., 2004, 2009a,b; Liu et al., 2004; Papadia and Hardingham, 2007; Hardingham, 2009). PS dose-dependently increased survival of cultured neurons after NMDA exposure (Fig. $1 E$ ) with an $\mathrm{EC}_{50}$ of $25 \pm 3 \mathrm{~nm}$ and significantly reduced $(p<0.01)$ the number of TUNEL-positive cells (supplemental Fig. $1 A, B$, available at www.jneurosci.org as supplemental material). Exposure of the DIV7 and the DIV21 mature cortical neurons (i.e., cultured for 7 and 21 DIV) to $300 \mu \mathrm{M}$ NMDA for $10 \mathrm{~min}$, increased caspase- 9 and caspase- 3 activities (Fig. $1 F, G$ ), but not caspase- 8 activity (supplemental Fig. $1 C$, available at www.jneurosci. org as supplemental material). This result essentially reproduced our published findings (Guo et al., 2004) and is consistent with several previous reports demonstrating caspase activation after NMDA challenge (Du et al., 1997; Budd et al., 2000; Tenneti et al., 2000; Okamoto et al., 2002; Madhavan et al., 2003; Liu et al., 2004; Guo et al., 2009b). The activation of both caspases was normalized by treatment with PS (Fig. $1 F, G$ ).

We have also tested different caspase inhibitors using the DIV7 and the DIV21 cultures. In both DIV7 and DIV21 neuronal cultures, we showed that caspase9-specific inhibitor ( $z$-LEDH-fmk) and caspase-3-specific inhibitor (Ac-DEVD$\mathrm{CHO}$ ), but not caspase-8-specific inhibitor (z-IETD-fmk) (Fig. $1 \mathrm{H}$ ), blocked the cell death similar as protein $\mathrm{S}$ did. These experiments confirm the role of the intrinsic apoptotic cascade and caspase-9mediated cell death after NMDA challenge both in immature and mature DIV21 neurons.

Using the same NMDA model (i.e., $300 \mu \mathrm{M}$ NMDA for $10 \mathrm{~min}$ ) and the DIV7 and the DIV21 neurons, we showed that NMDA induces nuclear translocation of AIF at later time points subsequent to caspase activation (Fig. 1I), as we and others reported in the DIV7 neurons (Guo et al., 2004) and the DIV14 neurons (Yu et al., 2002), respectively. The AIF translocation from the mitochondria to nucleus was blocked by protein S (Fig. 1 I). In the present NMDA model, caspase-3-specific inhibitor blocked AIF nuclear translocation in DIV7 and DIV21 neurons, indicating caspasedependent AIF nuclear translocation. Although it has been suggested that AIF function is caspase independent (Susin et al., 1999), several studies showed that AIF is released from mitochondria subsequent to activation of caspases, as for example in Caenorhabditis elegans (Wang, 2001), mouse cells (Guo et al., 2004), and human cells (Arnoult et al., 2002; Gabriel et al., 2003; Penninger and Kroemer, 2003), consistent with the present findings.

$\mathrm{F}$
B
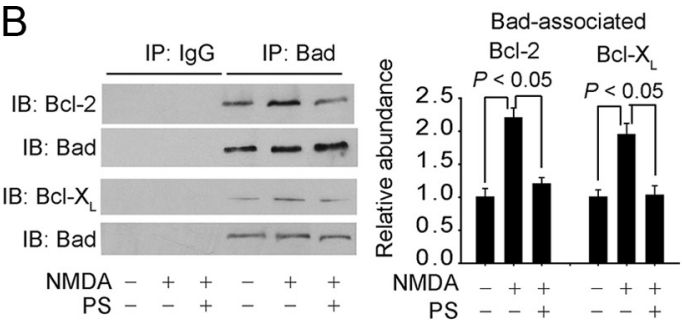

D

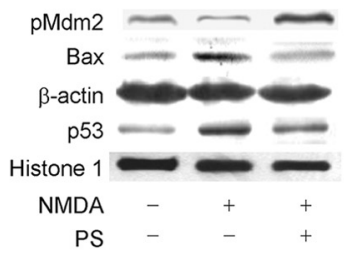

E
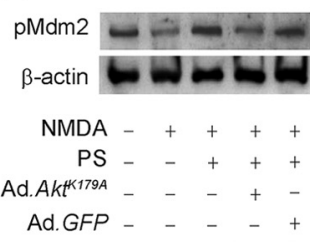

Ad. GFP $\quad P<0.05 \quad P<0.05$
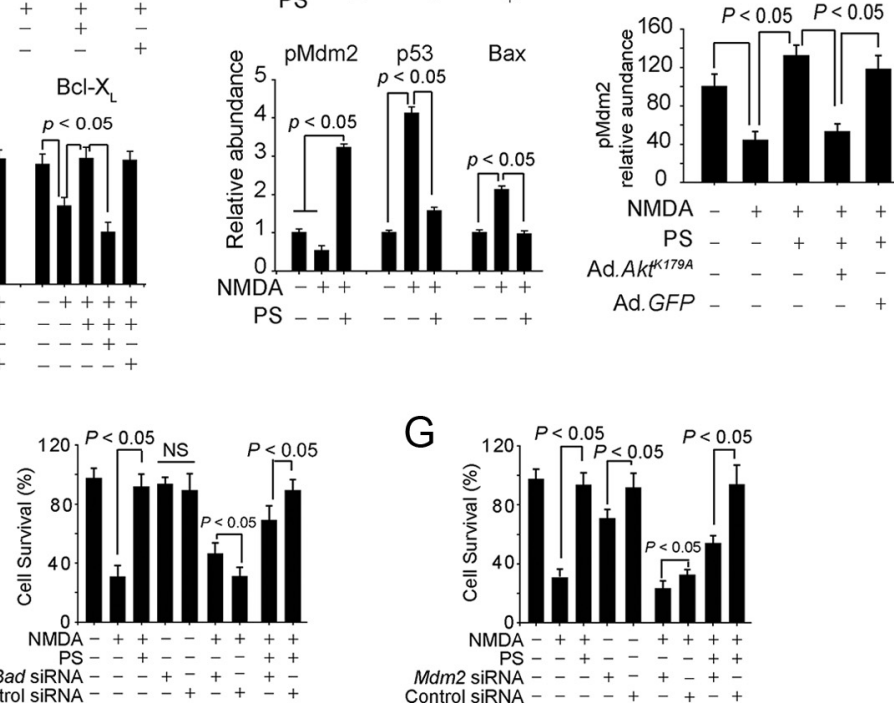

Figure 3. PS induces Akt phosphorylation of Bad and $M d m 2$, which increases free $B c l-2$ and $B c l-X_{L}$ levels and suppresses the proapoptotic p53/Bax pathway. A, Bad phosphorylation in mouse cortical neurons transduced with Ad.Akt ${ }^{K 179 A}$ or Ad.GFP $6 \mathrm{~h}$ after NMDA with or without PS. Graph, Relative abundance of $\mathrm{pBad}$ normalized to total Bad. $\boldsymbol{B}$, Bad-associated Bcl-2 and Bcl- $X_{\mathrm{L}}$ in mouse neurons $6 \mathrm{~h}$ after NMDA with and without PS determined by immunoprecipitation (IP) with anti-Bad antibody or nonimmune Ig ad-associated $\mathrm{BCl}-2$ and $\mathrm{BCl}-\mathrm{X}_{\mathrm{L}}$. C, BCl-2 and $\mathrm{BCl}-\mathrm{X}_{\mathrm{L}}$ levels in nontransduced mouse neurons and neurons transduced with or Ad.GFP6 $\mathrm{h}$ after NMDA with and without PS. D, Phosphorylated Mdm2, Bax, and nuclear p53 levels in mouse cortica 列 after NMDA with and without PS, and after transfection with Bad siRNA, Mdm2 siRNA, and control siRNA. Values are mean \pm SEM from three to six independent cultures. In all studies, cortical DIV7 neurons and murine PS at 100 nm were used.

Because Gas6, a structural analog of PS, activates the phosphatidylinositol 3-kinase (PI3K)/Akt survival pathway (Hafizi and Dahlbäck, 2006), we hypothesized that PS may also protect neurons through the PI3K/Akt pathway. Indeed, PS increased Akt phosphorylation dose-dependently with an $\mathrm{EC}_{50}$ of $26 \pm 4 \mathrm{nM}$ (Fig. 2A) and time-dependently (Fig. 2B). PS also increased Akt kinase activity, as indicated by phosphorylation of GSK- $3 \alpha / \beta$ crosstide (Fig. 2C) containing the Akt phosphorylation sites (i.e., Ser21 in GSK-3 $\alpha$ and Ser9 in GSK-3 $\beta$ ) and the same Akt phosphorylation motif $(\mathrm{R} / \mathrm{K}) \mathrm{X}(\mathrm{R} / \mathrm{K}) \mathrm{XX}\left(\mathrm{T}^{\star} / \mathrm{S}^{*}\right)$ as the other Akt downstream targets. LY294002, a PI3K-specific inhibitor, but not U0126 (a mitogen-activated protein kinase kinases 1/2-specific inhibitor), blocked PS-mediated Akt phosphorylation and neuronal protection after NMDA exposure (Fig. 2D,E), suggesting that PI3K/Akt pathway mediates PS neuroprotection. As re- 
A

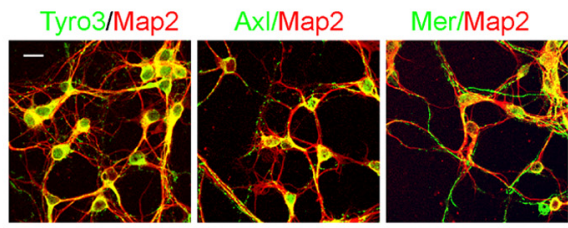

$B$

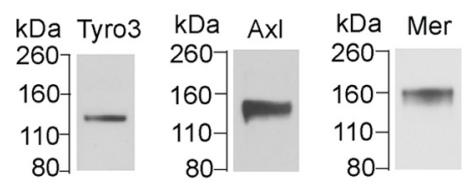

C

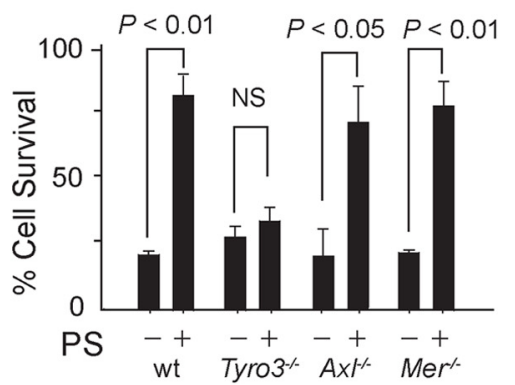

D
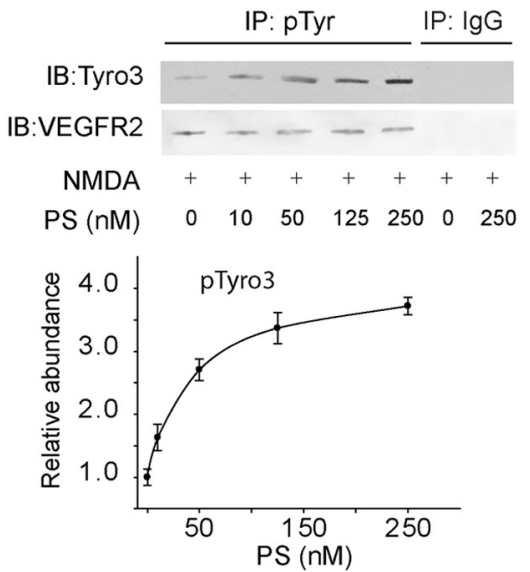

$\mathrm{E}$

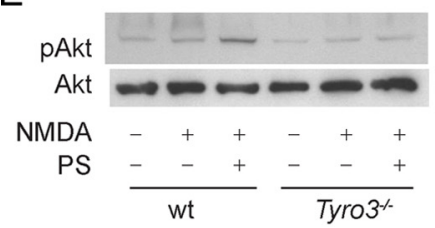

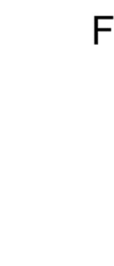

$\mathrm{F}$

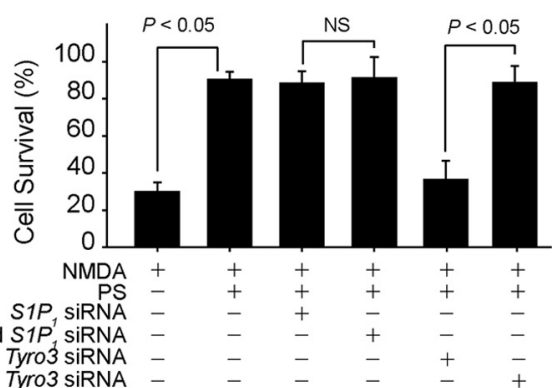

Figure 4. PS-mediated neuronal protection requires Tyro3 activation. $\boldsymbol{A}$, Double immunofluorescent staining of TAM receptors (green; Tyro3, Axl, and Mer) and neuronal marker Map2 (red) in mouse cortical neurons. Scale bar, $20 \mu \mathrm{m}$. B, Immunoblot analysis of Tyro3, Axl, and Mer in cultured mouse cortical neurons. C, Cell survival of mouse cortical neurons isolated from Tyro3, Axl, and Mer single mutants and control wt C57BL/6129 mice $24 \mathrm{~h}$ after NMDA with and without PS. D, PS dose-dependently mediates Tyro3 tyrosine phosphorylation in mouse cortical neurons as determined by immunoprecipitation (IP) with anti-phosphotyrosine (pTyr) antibody compared with control nonimmune lgG followed by immunoblotting (IB) with anti-Tyro3 antibody and antiVEGFR2 antibody (as a loading control) $2 \mathrm{~h}$ after NMDA. Graph, Relative abundance of phosphorylated Tyro3. $\boldsymbol{E}$, Akt phosphorylation (pAkt, Ser473) in neurons isolated from Tyro3 mutants and wt controls as above with and without PS $2 \mathrm{~h}$ after NMDA. $\boldsymbol{F}$, Cell survival of mouse cortical neurons $24 \mathrm{~h}$ after NMDA with and without PS, and after transfection with STP, siRNA, Tyro3 siRNA, and their respective scrambled control siRNAs. Values are mean \pm SEM; $n=3-6$ independent cultures. In all studies, DIV7 cortical neurons and murine PS at $100 \mathrm{~nm}$ were used, unless otherwise specified.

ported, LY294002 alone reduced cell survival by $\sim 10 \%$ (Fig. 2 E) consistent with a previous observation (Okayasu et al., 2003).

To demonstrate that Akt is the dominant pathway for neuronal protection by PS, cortical cells were transduced with recombinant adenovirus expressing a kinase-deficient Akt mutant (Ad. $A k t^{K 179 A}$ ) (Crowder and Freeman, 1998). The transduction efficiency was $\sim 70 \%$ (supplemental Fig. 2, available at www. jneurosci.org as supplemental material). Ad. $A k t^{K 179 A}$ expression, but not control Ad.GFP, abolished PS-mediated GSK- $3 \alpha / \beta$ phosphorylation (Fig. $2 \mathrm{~F}$ ) and neuronal protection both in DIV7 and DIV21 cortical neurons (Fig. 2G), suggesting that Akt activation is critical for PS-mediated neuronal protection.

We also showed that PS treatment stimulated phosphorylation of Bad and Mdm2, two downstream targets of Akt (Fig. 3). Nonphosphorylated Bad is proapoptotic because it binds the antiapoptotic Bcl-2 and Bcl- $\mathrm{X}_{\mathrm{L}}$ proteins (del Peso et al., 1997), whereas phosphorylated $\mathrm{pBad}$ does not bind Bcl-2 and Bcl- $\mathrm{X}_{\mathrm{L}}$ (Datta et al., 1997). PS led to an increase in phosphorylated Bad

on Ser136, a site phosphorylated by Akt, in nontransduced neurons and neurons transduced with Ad.GFP, but not in neurons expressing Ad. $A k t^{K 179 A}$ (Fig. 3A). PS-mediated Bad phosphorylation substantially reduced Bad-bound Bcl-2 and Bcl- $\mathrm{X}_{\mathrm{L}}$ in coimmunoprecipitation experiments with anti-Bad antibody but not with nonimmune IgG (Fig. $3 B$ ) and increased total Bcl-2 and $\mathrm{Bcl}-\mathrm{X}_{\mathrm{L}}$ levels (Fig. $3 C)$. These effects of PS were again lost in neurons transduced with Ad. $A k t^{K 179 A}$.

The tumor suppressor p53 transcription factor contributes to NMDA-mediated apoptosis in neurons by augmenting the activity of the proapoptotic Bax pathway (Guo et al., 2004, 2009a; Boutahar et al., 2008; Wang et al., 2009). Aktmediated phosphorylation of Mdm2 at sites including Ser 166 limits $\mathrm{p} 53$ proapoptotic activity by increasing $\mathrm{p} 53$ nuclear export (Mayo and Donner, 2001) and proteasomal degradation (Gottlieb et al., 2002). PS treatment stimulated phosphorylation of Mdm2 at Ser166 and reduced p53 and Bax levels by $\sim 90 \%$ in NMDA-treated nontransduced neurons (Fig. 3D) and neurons transduced with control Ad.GFP, but not in neurons expressing kinase-inactive Ad. $A k t^{K 179 A}$ (Fig. 3E).

To additionally confirm the contributions of the Bad and Mdm2 pathways in PS-mediated neuronal protection, we have performed experiments with siRNA inhibition of Bad (siBad) and Mdm2 (siMdm2). The respective siRNA-mediated knockdown inhibited by 96 and $91 \%$ Bad and Mdm2 protein expression, respectively (supplemental Fig. 3, available at www.jneurosci.org as supplemental material). Silencing Bad (siBad) in the absence of NMDA resulted in $\sim 95 \%$ survival, which in the present neuronal culture model was not significant compared with 96 and 92\% survival seen in control nontransfected neurons and neurons transfected with control siRNA (Fig. $3 F$ ), respectively. However, silencing Bad in NMDA-treated neurons increased neuronal survival compared with nontransfected neurons treated with NMDA or neurons transfected with control siRNA and treated with NMDA (Fig. 3F), consistent with a previous study showing that silencing Bcl-2 associated Bad suppresses rotenone-induced SH-SY5Y dopaminergic neuronal apoptosis (Hsuan et al., 2006). Silencing Bad, however, diminished by $\sim 30 \%$ PS-mediated protection of NMDA-treated neurons compared with control siRNA or basal conditions (Fig. $3 F$ ). A diminished PS-mediated protection of NMDA-treated neurons with $>95 \%$ Bad protein depletion (supplemental Fig. 3, available at www.jneurosci.org as supplemental material; Bad silencing) could likely be attributed to negligible levels of Bad that can be further phosphorylated by PS-Akt-dependent phosphorylation of Bad, in contrast to PS activity in NMDA-treated neurons with nonsilenced Bad when we showed that PS increased 
significantly the phosphorylated pBad levels (Fig. 3A), leading to significant reductions in Bad-associated $\mathrm{Bcl}-2$ and $\mathrm{Bcl}-\mathrm{X}_{\mathrm{L}}$ proteins (Fig. $3 B$ ) and increase in the antiapoptotic Bcl-2 and Bcl- $\mathrm{X}_{\mathrm{L}}$ levels (Fig. 3C). The present findings with PS are consistent with reports demonstrating that survival factors require Bad phosphorylation to prevent cell apoptosis (Datta et al., 2002; Ohi et al., 2006).

Figure $3 G$ shows that $\mathrm{Mdm} 2$ silencing (siMdm2) in the absence of NMDA reduced by $\sim 25 \%$ neuronal survival compared with neurons transfected with control siRNA or nontransfected neurons, consistent with previous reports demonstrating that inhibition of Mdm2 expression enhances neuronal and lung cancer cells death (Trinh et al., 2001; Guo et al., 2007). Silencing Mdm 2 compared with control siRNA also decreased by $25 \%$ survival of NMDA-treated neurons (Fig. 3G). However, in contrast to $94 \%$ survival of NMDA-treated neurons transfected with control siRNA and treated with PS, there was only $55 \%$ survival of NMDA-treated neurons transfected with siMdm2 and treated with PS, suggesting that inhibition of $\mathrm{Mdm} 2$ pathway significantly diminishes PS protection, as expected. These data show that both Bad and Mdm2 pathways contribute to PS-mediated neuronal protection.

Pathological overactivation of NMDARs increases free intracellular calcium concentration $\left[\mathrm{Ca}^{2+}\right]_{\mathrm{i}}$, which can activate the intrinsic apoptotic cascade (Papadia and Hardingham, 2007; Hardingham, 2009). A rapid increase in $\left[\mathrm{Ca}^{2+}\right]_{\mathrm{i}}$ from $\sim 100$ to $936 \mathrm{nM}$ occurred within $14 \mathrm{~s}$ of NMDA application (supplemental Fig. 4A, $B$, available at www.jneurosci.org as supplemental material), as reported previously (Tenneti et al., 1998). [ $\left.\mathrm{Ca}^{2+}\right]_{\mathrm{i}}$ levels were normalized within $2 \mathrm{~h}$ of NMDA removal consistent with a previous report (Tenneti et al., 1998) and remained within a range of basal values over the $24 \mathrm{~h}$ of NMDA removal (supplemental Fig. $4 B$, available at www. jneurosci.org as supplemental material), indicating that there is not an ongoing NMDAR activation. PS did not affect $\left[\mathrm{Ca}^{2+}\right]_{\mathrm{i}}$ levels before or after addition of NMDA (supplemental Fig. $4 A, B$, available at www.jneurosci.org as supplemental material), suggesting PS does not influence NMDA-induced $\mathrm{Ca}^{2+}$ influx.

It has been also reported that the brief exposure of primary mixed rat neuronal-glial cultures to NMDA (100 $\mu \mathrm{M}$ for $5 \mathrm{~min})$ can trigger release of glutamate into the culture medium close to $\sim 2.5 \mu \mathrm{mol} / \mathrm{L}$ that can activate the NMDARs (Strijbos et al., 1996). In the present model, however, glutamate levels in the medium were consistently $<1 \mu \mathrm{M}$ (supplemental Fig. $4 C$, available at www.jneurosci.org as supplemental material), which has been shown not to be sufficient to maintain an ongoing activation of NMDARs, as reported previously (Patneau and Mayer, 1990).
B

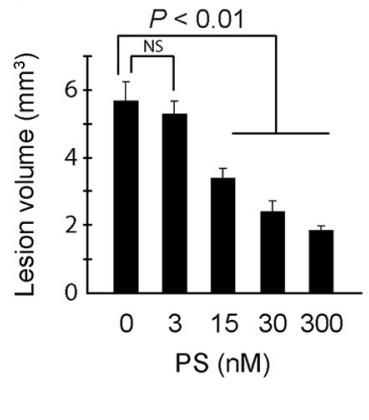

C

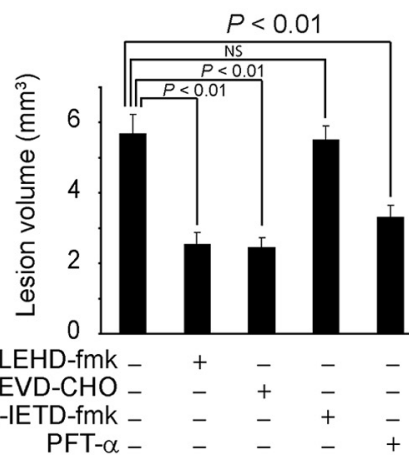

$E$

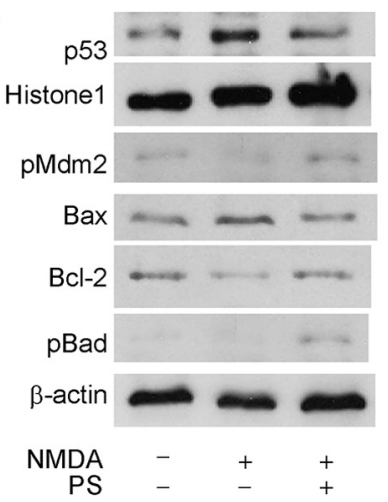

Figure 5. PS-mediated protection from NMDA-induced injury in the mouse brain in vivo requires Tyro3. $A$, Coronal sections of mouse brains with NMDA-induced excitotoxic lesions with and without murine PS ( $26 \mathrm{~nm}$ ) $48 \mathrm{~h}$ after NMDA administration. $\boldsymbol{B}$

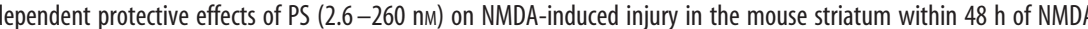
(z) 列 (wisthe $\mathbf{E}$, Immunoblot analysis of p53 nuclear levels (with hading control), and PS (260 nm). Values are mean \pm SEM; $n=3-6$ mice per group.

\section{Tyro 3 mediates in vitro and in vivo neuronal protection} by PS

The TAM receptors Tyro3, Axl, and Mer are expressed in cultured mouse cortical neurons as demonstrated by immunostaining (Fig. 4A) and immunoblotting (Fig. 4B). Studies using NMDA-challenged cortical neurons from $\mathrm{Tyro3}^{-1-}, \mathrm{Axl}^{-1-}$, and $\mathrm{Mer}^{-1-}$ transgenic mice and control wild-type mice indicated that PS protected control neurons and neurons lacking Axl and Mer, but failed to protect neurons lacking Tyro3 (Fig. 4C), suggesting a requirement of Tyro3 for PS-mediated neuronal protection. Consistent with this finding, we have demonstrated that mouse PS dose-dependently activates Tyro3 on mouse neurons by tyrosine phosphorylation with an $\mathrm{EC}_{50}$ of $25 \pm 3 \mathrm{~nm}$ (Fig. $4 D)$. We also showed that PS failed to activate Akt in NMDAtreated neurons lacking Tyro3 (Fig. $4 E$ ). Because $\mathrm{S}_{1} \mathrm{P}_{1}$ was shown to be involved in PS-mediated protection of the blood-brain barrier integrity (Zhu et al., 2010), the $\mathrm{S}_{1} \mathrm{P}_{1}$ silencing through RNA interference was used to determine whether $\mathrm{S}_{1} \mathrm{P}_{1}$ is required for PS-mediated neuronal protection. $S 1 P_{1}$-specific siRNA inhibited $\mathrm{S}_{1} \mathrm{P}_{1}$ protein expression by $>90 \%$ (data not shown). Neither 
A

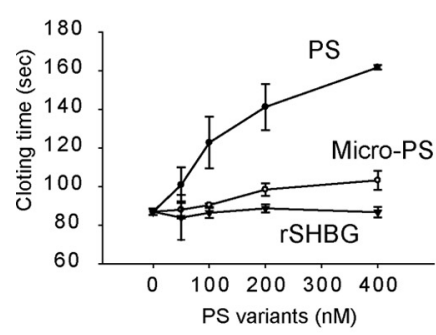

C

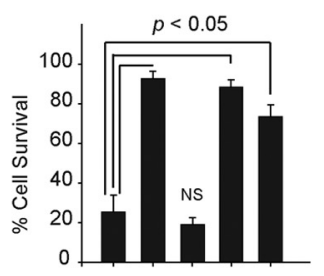

$\mathrm{NMDA}+++++$

PS - + - -

$\begin{array}{lllll}\text { Micro-PS }- & - & + & - & - \\ -T S R-P S & - & - & + & -\end{array}$

TSHBG
D

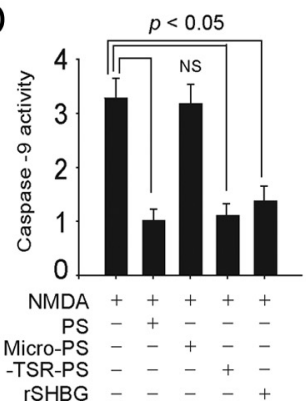

B
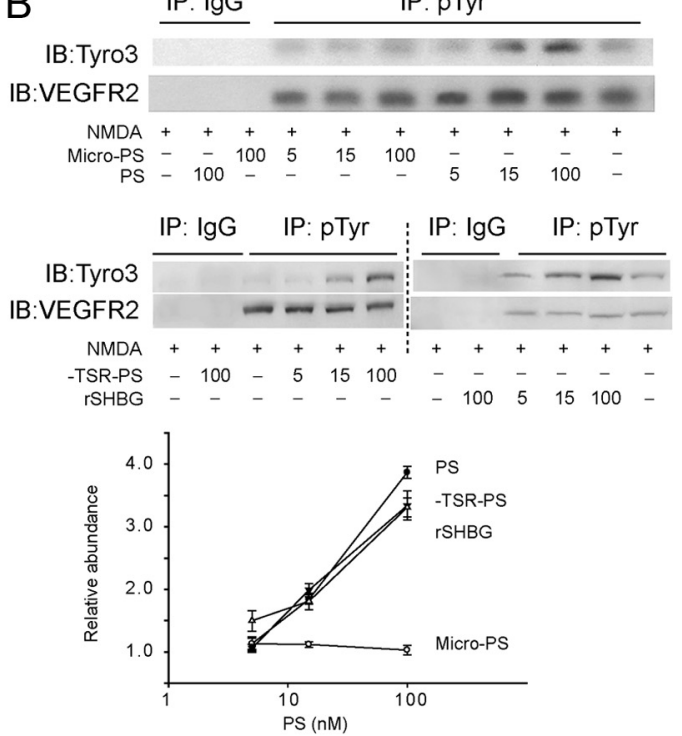

E

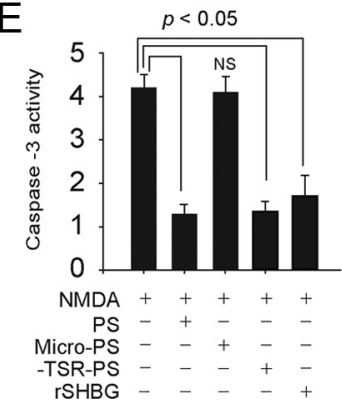

F

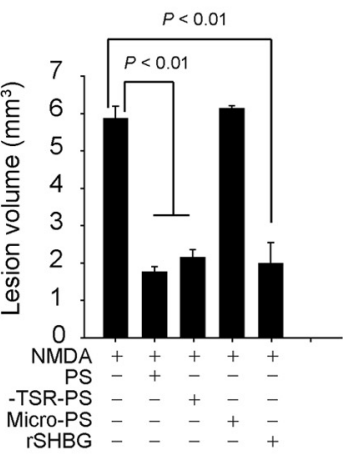

Figure 6. PS neuroprotection requires its SHBG-like domain. $A$, Anticoagulant activity in aPTT assays using PS-deficient plasma with exogenously added activated protein C and human recombinant PS $(\mathbf{O})$, synthetic micro-PS $(\bigcirc)$, and recombinant rSHBG ( $)$. Control PS unicalibrator lyophilized plasma contained 115\% PS. B, Tyro3 tyrosine phosphorylation in mouse cortical neurons as determined by immunoprecipitation (IP) with anti-phosphotyrosine (pTyr) antibody compared with control nonimmune lgG followed by immunoblotting (IB) with anti-Tyro3 and anti-VEGFR2 antibody (as a loading control) $2 \mathrm{~h}$ after NMDA treatment, respectively, in the presence of human recombinant PS, micro-PS, cleaved-PS (-TSR-PS), and rSHBG $(5,15$, and $100 \mathrm{~nm})$. Graph, Relative abundance of phosphorylated Tyro3. C, Cell survival of mouse cortical neurons $24 \mathrm{~h}$ after NMDA with and without human PS, cleaved PS (-TSR-PS), micro-PS, and rSHBG.D, E, Caspase-9 (D) and caspase-3 (E) activity in mouse cortical neurons 9 and $12 \mathrm{~h}$ after NMDA, respectively, in the presence of human PS, cleaved-PS (-TSR-PS), micro-PS, and rSHBG. In C-E, PS was used at 100 $n$ m. Values are mean $\pm S E M ; n=3-6$ independent cultures. $F$, NMDA-induced lesion in vivo in the striatum in wild-type mice in the presence of human PS, cleaved-PS ( - TSR-PS), micro-PS, and rSHBG, respectively. Values are mean \pm SEM; $n=3-6$ mice per group.

silencing $\mathrm{S}_{\mathrm{P}} \mathrm{P}_{1}$ nor control siRNA had any effect on PS-mediated neuroprotection after NMDA treatment (Fig. $4 F$ ), suggesting $\mathrm{S}_{1} \mathrm{P}_{1}$ is not involved in PS-mediated neuroprotection. In contrast, Tyro3 inhibition with Tyro3 siRNA (which inhibited Tyro3 expression by $>85 \%$ ) (data not shown) compared with control siRNA resulted in loss of PS-mediated neuroprotection (Fig. 4F).

We then studied whether PS can protect neurons from NMDA toxicity in vivo using an NMDA excitotoxic lesion model, as described previously (Ayata et al., 1997; Guo et al., 2004, 2009b). First, we showed that murine PS infused locally into the striatum dose-dependently reduced the NMDA-induced lesion volume (Fig. $5 A, B$ ), with 45 and $65 \%$ reductions at 15 and $26 \mathrm{~nm}$ PS, respectively, and with an $\mathrm{EC}_{50}$ of $22 \pm 2 \mathrm{~nm}$ (Fig. $5 B$ ).

To address whether cell death after NMDA injection into the mouse striatum in vivo depends on caspase activation as it does in cultured neurons, we tested the effects of caspase-9- and caspase-3-specific inhibitors on the volume of NMDA lesion. As shown in Figure $5 C$, both caspase- 9 and -3 inhibitors, but not caspase-8 inhibitor, infused locally into the CNS at concentrations previously shown to reduce the postischemic injury volume (Liu et al., 2004), also reduced significantly the NMDA lesion volume by $\sim 80 \%$ compared with the maximal reduction obtained with PS (which has been arbitrarily taken as $100 \%$ ). Moreover, caspase- 3 activity was increased by approximately eightfold in the injured striatum $24 \mathrm{~h}$ after NMDA injection that was blocked by $\sim 80 \%$ with PS (Fig. $5 D$ ). These findings suggest a major involvement of caspases in mediating cell death in the present NMDA model.

An increased p53 expression has been shown in the rat striatum after local administration of a NMDAR agonist quinolinic acid (Wang et al., 2009) or after NMDA injection into the mouse hippocampus (Djebaili et al., 2000). Previous studies have demonstrated increased p53 mRNA and protein expression after excitotoxic administration (Sakhi et al., 1996, 1997) and showed that p53 deficiency can spare neurons from apoptosis (Morrison et al., 1996; Xiang et al., 1996). To determine the role of $\mathrm{p} 53$ in the present NMDA in vivo model, we studied whether PFT- $\alpha$, a p53-specific inhibitor that was shown to block quinolinic acid-mediated p53dependent cell death in the rat striatum in vivo (Wang et al., 2009), can also reduce the NMDA lesion volume in mice. Our data show that PFT- $\alpha$ reduced substantially the NMDA lesion volume in the mouse striatum by $\sim 60 \%$ compared with the maximal reduction in the lesion volume obtained with PS (which has been arbitrarily taken as $100 \%)$. These data support an important role of p53 in the present NMDA model in vivo.

Consistent with a previous report demonstrating that $\mathrm{p} 53$ and Bax mediate NMDA-induced apoptosis in the mouse hippocampus in vivo (Djebaiili et al., 2000), we have also shown decreased pMdm2 levels and increased proapoptotic p53 and Bax levels in the striatum within $24 \mathrm{~h}$ of NMDA administration (Fig. 5E). NMDA administration decreased the levels of Bcl-2 as in cultured neurons. PS increased the levels of $\mathrm{pMdm} 2$ and decreased the levels of p53 and Bax suppressing this proapoptotic pathway in the striatum in vivo. PS also increased Bcl-2 and pBad levels in the striatum comparable with our findings in neuronal cultures.

Finally, we have confirmed that mouse neurons express all three TAM receptors in vivo with Tyro3 being predominantly expressed (data not shown), as reported previously (Prieto et al., 2000, 2007). However, whereas PS (260 nM) substantially reduced (by $\sim 65 \%$ ) the lesion volumes in control wild-type mice and $\mathrm{Axl}^{-1-}$ and $\mathrm{Mer}^{-1-}$ mice, it had no effect in $\mathrm{Tyro}^{-1-}$ mice 
(Fig. 5F). Collectively, these findings strongly imply that PS, which is a known ligand for Tyro3, protects neurons both in vitro and in vivo by binding and activating Tyro3. Furthermore, the neuronal protective activity of PS does not require Axl or Mer.

\section{The SHBG-like domain is required for PS-mediated neuronal protection in vitro and in vivo}

To identify domains of PS that mediate neuroprotection, we compared the protective activities of full-length PS, thrombin-cleaved PS (-TSR-PS), synthetic micro-protein $S$ (micro-PS), and recombinant SHBG (rSHBG) domain. As reported previously (Heeb and Griffin, 2002), thrombin cleaved rapidly PS at Arg49 within the TSR region (supplemental Fig. 5A, top, available at www.jneurosci. org as supplemental material), resulting in $>80 \%$ loss of its anticoagulant APCcofactor activity (supplemental Fig. 4B, available at www.jneurosci.org as supplemental material) (Heeb and Griffin, 2002). A slower, second cleavage at Arg70 (Fig. $5 A$, bottom) abolished completely the anticoagulant activity of PS within $24 \mathrm{~h}$, as reported previously (Heeb and Griffin, 2002). This second cleavage results in losses of the direct prothrombinase inhibitory activity of PS and its ability to bind to phospholipids (Heeb and Griffin, 2002). Micro-PS comprising the Gla, TSR, and EGF1 (Hackeng et al., 2000) expressed anticoagulant cofactor activity for APC that was $\sim 30 \%$ of full-length PS anticoagulant APC-cofactor activity (Fig. $6 A$ ). rSHBG did not have any anticoagulant activity (Fig. 6A), as reported previously (Saposnik et al., 2003).

PS, - TSR-PS, and rSHBG, but not micro-PS, dose-dependently and with comparable efficacy activated Tyro3 on mouse neurons as reflected in tyrosine phosphorylation (Fig. 6B). We found that -TSR-PS, which has an intact SHBG domain, and rSHBG, which lacks all the N-terminal domains of PS, exhibited a comparable protection of NMDA-treated neurons as fulllength PS (Fig. 6C). In contrast, micro-PS failed to protect NMDA-treated neurons. Similar, -TSR-PS and rSHBG, but not micro-PS, abolished NMDA-induced increases in caspase-9 (Fig. $6 D$ ) and caspase-3 (Fig. 6E) activities, comparably with that of full-length PS.

Using the NMDA in vivo model of excitotoxic lesions as above, we showed that the PS domains required for PS neuroprotection in vivo are the same as those required in vitro. Namely, PS, - TSR-PS, and rSHBG, which all contain the SHBG domain, but not micro-PS, which lacks the SHBG domain, similarly reduced the lesion volumes (Fig. $6 F$ ). These results indicate that nonanticoagulant - TSR-PS retains neuronal protective activity in vitro and in vivo, suggesting that a structurally intact TSR region is not required for PS-mediated neuroprotection, although it is required for anticoagulant APC-cofactor activity. A failure of micro-PS to exert neuroprotective activity shows that the Gla, TSR, and EGF1 regions are not sufficient for the cell survival properties of PS. Finally, the ability of rSHBG to protect neurons in vitro and in vivo directly shows that the SHBG-like domain is entirely sufficient for PS-mediated neuroprotection.

\section{Discussion}

The present study shows that PS protects neurons from excitotoxic NMDA-induced injury in vitro and in vivo by activating the TAM receptor Tyro3-PI3K-Akt pathway through its SHBG-like domain (Fig. 7).

Studies using Tyro3-, Axl-, and Mer-deficient neurons and transgenic mice have demonstrated that PS is a Tyro3 ligand both in vitro and in vivo. The TAM receptors form heterodimers (Lemke and Rothlin, 2008; Pierce et al., 2008), which increase complexity of the PS/Gas6-TAM receptors interactions. In the present study, PS fully protected Axl- and Mer-deficient neurons and $A x l^{-1-}$ and $\mathrm{Mer}^{-1-}$ transgenic mice from excitotoxic injury, suggesting Tyro3-Axl or Tyro3-Mer heterodimers likely have limited or no contribution to PS-mediated neuroprotection. The present findings may also raise a possibility that neuronal injury and seizures in Tyro3 mutants (Lu et al., 1999), apoptosis of the nervous tissue in triple TAM mutants (Lu and Lemke, 2001), and brain necrosis in mice lacking PS (Burstyn-Cohen et al., 2009; Saller et al., 2009) may at least in part be attributable to disrupted PS-Tyro3 interactions.

The PI3K/Akt pathway mediates Gas6-Axl (Goruppi et al., 1996; Konish et al., 2004; Valverde et al., 2004; Weinger et al., 2008) and Gas6-Tyro3 (Prieto et al., 2007) signaling. The present findings show that PS also activates the PI3K/Akt antiapoptotic signaling from the Tyro3 receptor in neurons, suggesting both PS and Gas 6 (Prieto et al., 2007) activate neuronal Tyro3. The key role of Akt in PS-mediated neuroprotection has been demonstrated in neurons transfected with a kinase-deficient $A k t^{\text {K179A }}$ (Crowder and Freeman, 1998), which exhibited a complete loss of PS-mediated protection. 
Pathological activation of NMDARs is a major cause of neuronal death after acute excitotoxic trauma such as brain ischemia, hypoxia, and mechanical trauma (Arundine and Tymianski, 2004). Chronic neurodegenerative disorders may also be associated with excessive NMDAR activation (Lipton and Rosenberg, 1994; Lipton, 2006). The NMDAR-mediated $\mathrm{Ca}^{2+}$ influx can result in cell survival or cell death signals (Papadia and Hardingham, 2007; Hardingham, 2009) depending on NMDAR location and subunit composition (Stanika et al., 2009). For example, selective activation of NR2A-contiaining NMDARs promotes neuronal survival, whereas NR2B-containing NMDARs induce cell death signals (Chen et al., 2007). Responses of neurons to glutamate and NMDA follow typically a bell-shaped curve (i.e., both too much and too little NMDAR activity is potentially harmful) (Lipton and Nakanishi, 1999). Depending on the stimulus intensity and neuronal cell type, some death pathways usually dominate over the others (Papadia and Hardingham, 2007; Hardingham, 2009).

In the present study, overstimulation of NMDARs increased both caspase- 9 and caspase- 3 activities, as previously reported (Du et al., 1997; Budd et al., 2000; Tenneti et al., 2000; Okamoto et al., 2002; Guo et al., 2004, 2009b). However, overstimulation of NMDARs can lead to caspase-independent death, as shown for example in the DIV14 mouse cortical neurons after exposure to a stronger NMDA signal [i.e., $500 \mu \mathrm{M}$ NMDA resulting in poly(ADP-ribose) polymerase-1 (PARP-1)-dependent cell death by AIF (Yu et al., 2002; Wang et al., 2004)]. In these studies, exposure of the DIV14 neurons to $500 \mu \mathrm{M}$ NMDA did not activate caspase-3. In contrast, PARP-1 activation was required for translocation of AIF from the mitochondria to the nucleus, and AIF was necessary for PARP-1-dependent cell death, resulting in caspase-independent pathway of programmed cell death (Yu et al., 2002; Wang et al., 2004).

Overstimulation of NMDARs leads to mitochondrial dysfunction, an increase in the Bax (proapoptotic)/Bcl-2 (antiapoptotic) ratio, generation of reactive oxygen/nitrogen species, p53 activation, calpain activation, P38 or JNK activation, etc., depending on the model (Papadia and Hardingham, 2007; Hardingham, 2009). In the present model, overstimulation of NMDARs led to mitochondrial dysfunction and depolarization of mitochondrial membrane with depletion of cytosolic ATP, reduction in the antiapoptotic $\mathrm{Bcl}-2$ and $\mathrm{Bcl}-\mathrm{X}_{\mathrm{L}}$ levels, and an increase in the proapoptotic p53 and Bax levels. Several studies have shown that p53 is an important upstream initiator of excitotoxic NMDA-induced neuronal death (Uberti et al., 1998; Djebailli et al., 2000; Jordán et al., 2003; Guo et al., 2004, 2009b; Boutahar et al., 2008; Wang et al., 2009). p53 can increase Bax/ $\mathrm{Bcl}-2$ (or Bcl- $\mathrm{X}_{\mathrm{L}}$ ) proapoptotic ratio through transcriptional Bax upregulation and/or Bax oligomerization (Zuckerman et al., 2009).

Our data show that PS blocks apoptotic signaling after NMDAR overstimulation by phosphorylating two downstream Akt targets, Bad and Mdm2 (Fig. 7). Nonphosphorylated Bad is a proapoptotic member of Bcl-2 family that binds and neutralizes the antiapoptotic Bcl-2 and Bcl-X $\mathrm{L}_{\mathrm{L}}$ (del Peso et al., 1997). In contrast, phosphorylated Bad cannot bind $\mathrm{Bcl}-2$ and $\mathrm{Bcl}-\mathrm{X}_{\mathrm{L}}$ (Datta et al., 1997). PS-Akt-mediated Bad phosphorylation resulted in dissociation of Bcl-2 and $\mathrm{Bcl}-\mathrm{X}_{\mathrm{L}}$ from Bad, increasing free levels of $\mathrm{Bcl}-2$ and $\mathrm{Bcl}-\mathrm{X}_{\mathrm{L}}$, which has resulted in cell protection. PS also blocked the proapoptotic p53-Bax signaling through Akt-mediated Mdm2 phosphorylation, which reduces p53 levels by increasing p53 nuclear export (Mayo and Donner, 2001) and degradation (Gottlieb et al., 2002). p53 blockade re- duces Bax levels (Guo et al., 2004, 2009b; Boutahar et al., 2008; Wang et al., 2009), which in turn increases Bcl-2 and Bcl- $\mathrm{X}_{\mathrm{L}}$ levels. An increase in total and free Bcl-2 and Bcl- $X_{L}$ levels was also shown to prevent drop in the mitochondrial membrane potential and ATP (Shimizu et al., 1996), as seen with PS therapy.

It is well known that Akt can protect against both caspasemediated cell death, as we and others have demonstrated (Dasari et al., 2008; Fuentealba et al., 2009; Jover-Mengual et al., 2010), and caspase-independent cell death, as reported previously (Luo et al., 2003; Kim et al., 2007; Yang et al., 2008). In certain caspaseindependent apoptosis models, Akt prevented AIF nuclear translocation, which inhibited cell death (Kim et al., 2007; Yang et al., 2008). In the present NMDA model, however, we have demonstrated that NMDA triggers AIF nuclear translocation at later time points subsequent to caspase activation and in caspasedependent manner consistent with previous work (Wang, 2001; Arnoult et al., 2002; Gabriel et al., 2003; Penninger and Kroemer, 2003; Guo et al., 2004). Moreover, by inhibiting Mdm2 and Bad in cortical neurons using the siRNA strategy, we have confirmed that Akt-mediated regulation of these apoptotic targets has the primary role in PS-mediated neuroprotection.

The binding of PS to Tyro3 is mediated by the first LG (lami$\operatorname{nin} G$ ) region within SHBG domain (Evenäs et al., 2000). Using different PS structural analogs, we showed that the $\mathrm{N}$ terminus Gla domain, TSR region, and EGF1 domain are not required for PS-mediated neuroprotection in vitro and in vivo. In contrast, the C terminus SHBG domain was both necessary and sufficient to activate Tyro3 and achieve neuronal protection. Compared with full-length anticoagulant PS, a smaller non-anticoagulant SHBG module exerts a comparable neuroprotection but does not have any bleeding risk.

Recently, it has been reported that PS stabilizes the bloodbrain barrier integrity via Tyro3 and $\mathrm{S}_{1} \mathrm{P}_{1}$-mediated Rac1dependent signaling (Zhu et al., 2010). The present siRNA silencing experiment indicated, however, that $\mathrm{S}_{1} \mathrm{P}_{1}$ was not involved in PS-mediated neuroprotection against excitotoxic injury. The discrepancy between the present and a previous study possibly reflects differential receptors requirements for PSmediated neuronal protection and cytoskeleton reorganization in the endothelium (Zhu et al., 2010). In contrast, Tyro3 inhibition by the Tyro3 siRNA resulted in loss of PS-mediated neuroprotection, which has independently confirmed our findings in Tyro3-null neurons. Nevertheless, future studies using transgenic models with specific deletions of Tyro3 and $\mathrm{S}_{1} \mathrm{P}_{1}$ from brain endothelium and neurons should further evaluate the exact roles of Tyro3-S1P $\mathrm{P}_{1}$-mediated $\mathrm{BBB}$ protection and Tyro3mediated neuronal protection in the overall beneficial effects of PS therapy in models of acute brain injury and other neurological conditions.

In sum, our data support development of novel PS-based neuroprotective approaches for reducing acute brain injury and possibly for mitigating chronic neurodegenerative disorders associated with excessive activation of NMDARs.

\section{References}

Anderson HA, Maylock CA, Williams JA, Paweletz CP, Shu H, Shacter E (2003) Serum-derived protein S binds to phosphatidylserine and stimulates the phagocytosis of apoptotic cells. Nat Immunol 4:87-91.

Arnoult D, Parone P, Martinou JC, Antonsson B, Estaquier J, Ameisen JC (2002) Mitochondrial release of apoptosis-inducing factor occurs downstream of cytochrome $c$ release in response to several proapoptotic stimuli. J Cell Biol 159:923-929.

Arundine M, Tymianski M (2004) Molecular mechanisms of glutamate- 
dependent neurodegeneration in ischemia and traumatic brain injury. Cell Mol Life Sci 61:657-668.

Ayata C, Ayata G, Hara H, Matthews RT, Beal MF, Ferrante RJ, Endres M, Kim A, Christie RH, Waeber C, Huang PL, Hyman BT, Moskowitz MA (1997) Mechanisms of reduced striatal NMDA excitotoxicity in type I nitric oxide synthase knock-out mice. J Neurosci 17:6908-6917.

Benzakour O, Formstone C, Rahman S, Kanthou C, Dennehy U, Scully MF, Kakkar VV, Cooper DN (1995) Evidence for a protein S receptor(s) on human vascular smooth muscle cells. Analysis of the binding characteristics and mitogenic properties of protein $S$ on human vascular smooth muscle cells. Biochem J 308:481-485.

Bonfoco E, Krainc D, Ankarcrona M, Nicotera P, Lipton SA (1995) Apoptosis and necrosis: two distinct events induced, respectively, by mild and intense insults with $\mathrm{N}$-methyl-D-aspartate or nitric oxide/superoxide in cortical cell cultures. Proc Natl Acad Sci U S A 92:7162-7166.

Boutahar N, Reynaud E, Lassabliere F, Borg J (2008) Timing differences of signaling response in neuron cultures activated by glutamate analogue or free radicals. Brain Res 1191:20-29.

Budd SL, Tenneti L, Lishnak T, Lipton SA (2000) Mitochondrial and extramitochondrial apoptotic signaling pathways in cerebrocortical neurons. Proc Natl Acad Sci U S A 97:6161-6166.

Burstyn-Cohen T, Heeb MJ, Lemke G (2009) Lack of protein S in mice causes embryonic lethal coagulopathy and vascular dysgenesis. J Clin Invest 119:2942-2953.

Chen Q, He S, Hu XL, Yu J, Zhou Y, Zheng J, Zhang S, Zhang C, Duan WH, Xiong ZQ (2007) Differential roles of NR2A- and NR2B-containing NMDA receptors in activity-dependent brain-derived neurotrophic factor gene regulation and limbic epileptogenesis. J Neurosci 27:542-552.

Crowder RJ, Freeman RS (1998) Phosphatidylinositol 3-kinase and Akt protein kinase are necessary and sufficient for the survival of nerve growth factor-dependent sympathetic neurons. J Neurosci 18:2933-2943.

Dahlbäck B (2007) The tale of protein S and C4b-binding protein, a story of affection. Thromb Haemost 98:90-96.

Dasari VR, Veeravalli KK, Saving KL, Gujrati M, Fassett D, Klopfenstein JD, Dinh DH, Rao JS (2008) Neuroprotection by cord blood stem cells against glutamate-induced apoptosis is mediated by Akt pathway. Neurobiol Dis 32:486-498.

Datta SR, Dudek H, Tao X, Masters S, Fu H, Gotoh Y, Greenberg ME (1997) Akt phosphorylation of BAD couples survival signals to the cell-intrinsic death machinery. Cell 91:231-241.

Datta SR, Ranger AM, Lin MZ, Sturgill JF, Ma YC, Cowan CW, Dikkes P, Korsmeyer SJ, Greenberg ME (2002) Survival factor-mediated BAD phosphorylation raises the mitochondrial threshold for apoptosis. Dev Cell 3:631-643.

del Peso L, González-García M, Page C, Herrera R, Nuñez G (1997) Interleukin-3-induced phosphorylation of $\mathrm{BAD}$ through the protein kinase Akt. Science 278:687-689.

Djebailli M, Rondouin G, Baille V, Bockaert J (2000) p53 and Bax implication in NMDA induced-apoptosis in mouse hippocampus. Neuroreport 11:2973-2976.

Dömötör E, Benzakour O, Griffin JH, Yule D, Fukudome K, Zlokovic BV (2003) Activated protein C alters cytosolic calcium flux in human brain endothelium val binding to endothelial protein $\mathrm{C}$ receptor and activation of protease activated receptor-1. Blood 101:4797-4801.

Du Y, Bales KR, Dodel RC, Hamilton-Byrd E, Horn JW, Czilli DL, Simmons LK, Ni B, Paul SM (1997) Activation of a caspase 3-related cysteine protease is required for glutamate-mediated apoptosis of cultured cerebellar granule neurons. Proc Natl Acad Sci U S A 94:11657-11662.

Evenäs P, Dahlbäck B, García de Frutos P (2000) The first laminin G-type domain in the SHBG-like region of protein $S$ contains residues essential for activation of the receptor tyrosine kinase sky. Biol Chem 381:199-209.

Fernández JA, Heeb MJ, Xu X, Singh I, Zlokovic BV, Griffin JH (2009) Species-specific anticoagulant and mitogenic activities of murine protein S. Haematologica 94:1721-1731.

Fuentealba RA, Liu Q, Kanekiyo T, Zhang J, Bu G (2009) Low density lipoprotein receptor-related protein 1 promotes anti-apoptotic signaling in neurons by activating Akt survival pathway. J Biol Chem 284:34045-34053.

Gabriel B, Sureau F, Casselyn M, Teissié J, Petit PX (2003) Retroactive pathway involving mitochondria in electroloaded cytochrome $c$-induced apoptosis. Protective properties of Bcl-2 and Bcl-XL. Exp Cell Res 289:195-210.
Gasic GP, Arenas CP, Gasic TB, Gasic GJ (1992) Coagulation factors X, Xa, and protein $\mathrm{S}$ as potent mitogens of cultured aortic smooth muscle cells. Proc Natl Acad Sci U S A 89:2317-2320.

Goruppi S, Ruaro E, Schneider C (1996) Gas6, the ligand of Axl tyrosine kinase receptor, has mitogenic and survival activities for serum starved NIH3T3 fibroblasts. Oncogene 12:471-480.

Gottlieb TM, Leal JF, Seger R, Taya Y, Oren M (2002) Cross-talk between Akt, p53 and Mdm2: possible implications for the regulation of apoptosis. Oncogene 21:1299-1303.

Guo H, Liu D, Gelbard H, Cheng T, Insalaco R, Fernández JA, Griffin JH, Zlokovic BV (2004) Activated protein C prevents neuronal apoptosis via protease activated receptors 1 and 3. Neuron 41:563-572.

Guo H, Singh I, Wang Y, Deane R, Barrett T, Fernández JA, Chow N, Griffin JH, Zlokovic BV (2009a) Neuroprotective activities of activated protein C mutant with reduced anticoagulant activity. Eur J Neurosci 29: $1119-1130$

Guo H, Wang Y, Singh I, Liu D, Fernández JA, Griffin JH, Chow N, Zlokovic BV (2009b) Species-dependent neuroprotection by activated protein C mutants with reduced anticoagulant activity. J Neurochem 109:116-124.

Guo W, Ahmed KM, Hui Y, Guo G, Li JJ (2007) siRNA-mediated Mdm2 inhibition sensitizes human lung cancer A549 cells to radiation. Int J Oncol 30:1447-1452.

Hackeng TM, Fernández JA, Dawson PE, Kent SB, Griffin JH (2000) Chemical synthesis and spontaneous folding of a multidomain protein: anticoagulant microprotein S. Proc Natl Acad Sci U S A 97:14074-14078.

Hafizi S, Dahlbäck B (2006) Gas6 and protein S. Vitamin K-dependent ligands for the Axl receptor tyrosine kinase subfamily. FEBS J 273:5231-5244.

Hall MO, Obin MS, Heeb MJ, Burgess BL, Abrams TA (2005) Both protein $\mathrm{S}$ and Gas6 stimulate outer segment phagocytosis by cultured rat retinal pigment epithelial cells. Exp Eye Res 81:581-591.

Hardingham GE (2009) Coupling of the NMDA receptor to neuroprotective and neurodestructive events. Biochem Soc Trans 37:1147-1160.

Heeb MJ, Griffin JH (2002) Activated protein C-dependent and -independent anticoagulant activities of protein $\mathrm{S}$ have different structural requirements. Blood Cells Mol Dis 29:190-199.

Hori N, Carpenter DO (1994) Functional and morphological changes induced by transient in vivo ischemia. Exp Neurol 129:279-289.

Hsuan SL, Klintworth HM, Xia Z (2006) Basic fibroblast growth factor protects against rotenone-induced dopaminergic cell death through activation of extracellular signal-regulated kinases $1 / 2$ and phosphatidylinositol- 3 kinase pathways. J Neurosci 26:4481-4491.

Jamison CS, McDowell SA, Marlar RA, Degen SJ (1995) Developmental expression of protein $\mathrm{C}$ and protein $\mathrm{S}$ in the rat. Thromb Res 78:407-419.

Jordán J, Galindo MF, González-García C, Ceña V (2003) Role and regulation of p53 in depolarization-induced neuronal death. Neuroscience 122:707-715.

Jover-Mengual T, Miyawaki T, Latuszek A, Alborch E, Zukin RS, Etgen AM (2010) Acute estradiol protects CA1 neurons from ischemia-induced apoptotic cell death via the PI3K/Akt pathway. Brain Res 1321:1-12.

Kajimoto T, Okada T, Yu H, Goparaju SK, Jahangeer S, Nakamura S (2007) Involvement of sphingosine-1-phosphate in glutamate secretion in hippocampal neurons. Mol Cell Biol 27:3429-3440.

Kakee A, Terasaki T, Sugiyama Y (1996) Brain efflux index as a novel method of analyzing efflux transport at the blood-brain barrier. J Pharmacol Exp Ther 277:1550-1559.

Kim NH, Kim K, Park WS, Son HS, Bae Y (2007) PKB/Akt inhibits ceramide-induced apoptosis in neuroblastoma cells by blocking apoptosis-inducing factor (AIF) translocation. J Cell Biochem 102:1160-1170.

Konishi A, Aizawa T, Mohan A, Korshunov VA, Berk BC (2004) Hydrogen peroxide activates the Gas6-Axl pathway in vascular smooth muscle cells. J Biol Chem 279:28766-28770.

Lemke G, Lu Q (2003) Macrophage regulation by Tyro 3 family receptors. Curr Opin Immunol 15:31-36.

Lemke G, Rothlin CV (2008) Immunobiology of the TAM receptors. Nat Rev Immunol 8:327-336.

Lesuisse C, Martin LJ (2002a) Long-term culture of mouse cortical neurons as a model for neuronal development, aging, and death. J Neurobiol 51:9-23.

Lesuisse C, Martin LJ (2002b) Immature and mature cortical neurons engage different apoptotic mechanisms involving caspase- 3 and the 
mitogen-activated protein kinase pathway. J Cereb Blood Flow Metab 22:935-950.

Lipton SA (2006) NMDA receptors, glial cells, and clinical medicine. Neuron 50:9-11.

Lipton SA, Nakanishi N (1999) Shakespeare in love-with NMDA receptors? Nat Med 5:270-271.

Lipton SA, Rosenberg PA (1994) Excitatory amino acids as a final common pathway for neurologic disorders. N Engl J Med 330:613-622.

Liu D, Guo H, Griffin JH, Fernández JA, Zlokovic BV (2003) Protein S confers neuronal protection during ischemic/hypoxic injury in mice. Circulation 107:1791-1796.

Liu D, Cheng T, Guo H, Fernández JA, Griffin JH, Song X, Zlokovic BV (2004) Tissue plasminogen activator neurovascular toxicity is controlled by activated protein C. Nat Med 10:1379-1383.

Lu Q, Lemke G (2001) Homeostatic regulation of the immune system by receptor tyrosine kinases of the Tyro 3 family. Science 293:306-311.

Lu Q, Gore M, Zhang Q, Camenisch T, Boast S, Casagranda F, Lai C, Skinner MK, Klein R, Matsushima GK, Earp HS, Goff SP, Lemke G (1999) Tyro-3 family receptors are essential regulators of mammalian spermatogenesis. Nature 398:723-728.

Luo HR, Hattori H, Hossain MA, Hester L, Huang Y, Lee-Kwon W, Donowitz M, Nagata E, Snyder SH (2003) Akt as a mediator of cell death. Proc Natl Acad Sci U S A 100:11712-11717.

Madhavan L, Freed WJ, Anantharam V, Kanthasamy AG (2003) 5-Hydroxytryptamine $1 \mathrm{~A}$ receptor activation protects against $\mathrm{N}$-methyl-Daspartate-induced apoptotic cell death in striatal and mesencephalic cultures. J Pharmacol Exp Ther 304:913-923.

Mayo LD, Donner DB (2001) A phosphatidylinositol 3-kinase/Akt pathway promotes translocation of $\mathrm{Mdm} 2$ from the cytoplasm to the nucleus. Proc Natl Acad Sci U S A 98:11598-11603.

Morrison RS, Wenzel HJ, Kinoshita Y, Robbins CA, Donehower LA, Schwartzkroin PA (1996) Loss of the p53 tumor suppressor gene protects neurons from kainate-induced cell death. J Neurosci 16:1337-1345.

Nakatsu Y, Kotake Y, Komasaka K, Hakozaki H, Taguchi R, Kume T, Akaike A, Ohta S (2006) Glutamate excitotoxicity is involved in cell death caused by tributyltin in cultured rat cortical neurons. Toxicol Sci 89:235-242.

Ohi N, Nishikawa Y, Tokairin T, Yamamoto Y, Doi Y, Omori Y, Enomoto K (2006) Maintenance of Bad phosphorylation prevents apoptosis of rat hepatic sinusoidal endothelial cells in vitro and in vivo. Am J Pathol 168:1097-1106.

Okamoto S, Li Z, Ju C, Scholzke MN, Mathews E, Cui J, Salvesen GS, BossyWetzel E, Lipton SA (2002) Dominant-interfering forms of MEF2 generated by caspase cleavage contribute to NMDA-induced neuronal apoptosis. Proc Natl Acad Sci U S A 99:3974-3979.

Okayasu R, Takakura K, Poole S, Bedford JS (2003) Radiosensitization of normal human cells by LY294002: cell killing and the rejoining of DNA and interphase chromosome breaks. J Radiat Res (Tokyo) 44:329-333.

Papadia S, Hardingham GE (2007) The dichotomy of NMDA receptor signaling. Neuroscientist 13:572-579.

Patneau DK, Mayer ML (1990) Structure-activity relationships for amino acid transmitter candidates acting at $N$-methyl-D-aspartate and quisqualate receptors. J Neurosci 10:2385-2399.

Penninger JM, Kroemer G (2003) Mitochondria, AIF and caspases-rivaling for cell death execution. Nat Cell Biol 5:97-99.

Phillips DJ, Greengard JS, Fernández JA, Ribeiro M, Evatt BL, Griffin JH, Hooper WC (1993) Protein S, an antithrombotic factor, is synthesized and released by neural tumor cells. J Neurochem 61:344-347.

Pierce A, Bliesner B, Xu M, Nielsen-Preiss S, Lemke G, Tobet S, Wierman ME (2008) Axl and Tyro3 modulate female reproduction by influencing gonadotropin-releasing hormone neuron survival and migration. Mol Endocrinol 22:2481-2495.

Prasad D, Rothlin CV, Burrola P, Burstyn-Cohen T, Lu Q, Garcia de Frutos P, Lemke G (2006) TAM receptor function in the retinal pigment epithelium. Mol Cell Neurosci 33:96-108.

Prieto AL, Weber JL, Lai C (2000) Expression of the receptor proteintyrosine kinases Tyro-3, Axl, and mer in the developing rat central nervous system. J Comp Neurol 425:295-314.

Prieto AL, O’Dell S, Varnum B, Lai C (2007) Localization and signaling of the receptor protein tyrosine kinase Tyro3 in cortical and hippocampal neurons. Neuroscience 150:319-334.

Rothlin CV, Ghosh S, Zuniga EI, Oldstone MB, Lemke G (2007) TAM re- ceptors are pleiotropic inhibitors of the innate immune response. Cell 131:1124-1136.

Sakhi S, Sun N, Wing LL, Mehta P, Schreiber SS (1996) Nuclear accumulation of p53 protein following kainic acid-induced seizures. Neuroreport 7:493-496.

Sakhi S, Bruce A, Sun N, Tocco G, Baudry M, Schreiber SS (1997) Induction of tumor suppressor p53 and DNA fragmentation in organotypic hippocampal cultures following excitotoxin treatment. Exp Neurol 145: $81-88$.

Saller F, Villoutreix BO, Amelot A, Kaabache T, Le Bonniec BF, Aiach M, Gandrille S, Borgel D (2005) The gamma-carboxyglutamic acid domain of anticoagulant protein $\mathrm{S}$ is involved in activated protein $\mathrm{C}$ cofactor activity, independently of phospholipid binding. Blood 105:122-130.

Saller F, Brisset AC, Tchaikovski SN, Azevedo M, Chrast R, Fernández JA, Schapira M, Hackeng TM, Griffin JH, Angelillo-Scherrer A (2009) Generation and phenotypic analysis of protein S-deficient mice. Blood 114:2307-2314

Saposnik B, Borgel D, Aiach M, Gandrille S (2003) Functional properties of the sex-hormone-binding globulin (SHBG)-like domain of the anticoagulant protein S. Eur J Biochem 270:545-555.

Shankar SL, O'Guin K, Kim M, Varnum B, Lemke G, Brosnan CF, ShafitZagardo B (2006) Gas6/Axl signaling activates the phosphatidylinositol 3-kinase/Akt1 survival pathway to protect oligodendrocytes from tumor necrosis factor $\alpha$-induced apoptosis. J Neurosci 26:5638-5648.

Shimizu S, Eguchi Y, Kamiike W, Waguri S, Uchiyama Y, Matsuda H, Tsujimoto Y (1996) Bcl-2 blocks loss of mitochondrial membrane potential while ICE inhibitors act at a different step during inhibition of death induced by respiratory chain inhibitors. Oncogene 13:21-29.

Stanika RI, Pivovarova NB, Brantner CA, Watts CA, Winters CA, Andrews SB (2009) Coupling diverse routes of calcium entry to mitochondrial dysfunction and glutamate excitotoxicity. Proc Natl Acad Sci U S A 106:9854-9859.

Stitt TN, Conn G, Gore M, Lai C, Bruno J, Radziejewski C, Mattsson K, Fisher J, Gies DR, Jones PF (1995) The anticoagulation factor protein $S$ and its relative, Gas6, are ligands for the Tyro 3/Axl family of receptor tyrosine kinases. Cell 80:661-670.

Strijbos PJ, Leach MJ, Garthwaite J (1996) Vicious cycle involving $\mathrm{Na}^{+}$ channels, glutamate release, and NMDA receptors mediates delayed neurodegeneration through nitric oxide formation. J Neurosci 16:50045013.

Susin SA, Lorenzo HK, Zamzami N, Marzo I, Snow BE, Brothers GM, Mangion J, Jacotot E, Costantini P, Loeffler M, Larochette N, Goodlett DR, Aebersold R, Siderovski DP, Penninger JM, Kroemer G (1999) Molecular characterization of mitochondrial apoptosis-inducing factor. Nature 397:441-446.

Takeuchi H, Mizuno T, Zhang G, Wang J, Kawanokuchi J, Kuno R, Suzumura A (2005) Neuritic beading induced by activated microglia is an early feature of neuronal dysfunction toward neuronal death by inhibition of mitochondrial respiration and axonal transport. J Biol Chem 280:10444-10454.

Tan Z, Sun X, Hou FS, Oh HW, Hilgenberg LG, Hol EM, van Leeuwen FW, Smith MA, O'Dowd DK, Schreiber SS (2007) Mutant ubiquitin found in Alzheimer's disease causes neuritic beading of mitochondria in association with neuronal degeneration. Cell Death Differ 14:1721-1732.

Tenneti L, Lipton SA (2000) Involvement of activated caspase-3-like proteases in $N$-methyl-D-aspartate-induced apoptosis in cerebrocortical neurons. J Neurochem 74:134-142.

Tenneti L, D'Emilia DM, Troy CM, Lipton SA (1998) Role of caspases in $N$-methyl-D-aspartate-induced apoptosis in cerebrocortical neurons. J Neurochem 71:946-959.

Trinh E, Boutillier AL, Loeffler JP (2001) Regulation of the retinoblastomadependent Mdm2 and E2F-1 signaling pathways during neuronal apoptosis. Mol Cell Neurosci 17:342-353.

Uberti D, Belloni M, Grilli M, Spano P, Memo M (1998) Induction of tumour-suppressor phosphoprotein $\mathrm{p} 53$ in the apoptosis of cultured rat cerebellar neurones triggered by excitatory amino acids. Eur J Neurosci $10: 246-254$.

Uehara H, Shacter E (2008) Auto-oxidation and oligomerization of protein $\mathrm{S}$ on the apoptotic cell surface is required for Mer tyrosine kinasemediated phagocytosis of apoptotic cells. J Immunol 180:2522-2530.

Valverde P, Obin MS, Taylor A (2004) Role of Gas6/Axl signaling in lens epithelial cell proliferation and survival. Exp Eye Res 78:27-37. 
Wang H, Yu SW, Koh DW, Lew J, Coombs C, Bowers W, Federoff HJ, Poirier GG, Dawson TM, Dawson VL (2004) Apoptosis-inducing factor substitutes for caspase executioners in NMDA-triggered excitotoxic neuronal death. J Neurosci 24:10963-10973.

Wang X (2001) The expanding role of mitochondria in apoptosis. Genes Dev 15:2922-2933.

Wang Y, Dong XX, Cao Y, Liang ZQ, Han R, Wu JC, Gu ZL, Qin ZH (2009) p53 induction contributes to excitotoxic neuronal death in rat striatum through apoptotic and autophagic mechanisms. Eur J Neurosci 30:22582270 .

Webb JH, Blom AM, Dahlbäck B (2002) Vitamin K-dependent protein S localizing complement regulator $\mathrm{C} 4 \mathrm{~b}$-binding protein to the surface of apoptotic cells. J Immunol 169:2580-2586.

Weinger JG, Gohari P, Yan Y, Backer JM, Varnum B, Shafit-Zagardo B (2008) In brain, Axl recruits Grb2 and the p 85 regulatory subunit of PI3 kinase; in vitro mutagenesis defines the requisite binding sites for downstream Akt activation. J Neurochem 106:134-146.

Woodhouse A, Vickers JC, Adlard PA, Dickson TC (2009) Dystrophic neurites in TgCRND8 and Tg2576 mice mimic human pathological brain aging. Neurobiol Aging 30:864-874.
Xiang H, Hochman DW, Saya H, Fujiwara T, Schwartzkroin PA, Morrison RS (1996) Evidence for p53-mediated modulation of neuronal viability. J Neurosci 16:6753-6765.

Yang X, Fraser M, Abedini MR, Bai T, Tsang BK (2008) Regulation of apoptosis-inducing factor-mediated, cisplatin-induced apoptosis by Akt. Br J Cancer 98:803-808.

Yu SW, Wang H, Poitras MF, Coombs C, Bowers WJ, Federoff HJ, Poirier GG, Dawson TM, Dawson VL (2002) Mediation of poly(ADP-ribose) polymerase-1-dependent cell death by apoptosis-inducing factor. Science 297:259-263.

Zhong J, Russell SL, Pritchett DB, Molinoff PB, Williams K (1994) Expression of mRNAs encoding subunits of the $N$-methyl-D-aspartate receptor in cultured cortical neurons. Mol Pharmacol 45:846-853.

Zhu D, Wang Y, Singh I, Bell RD, Deane R, Zhong Z, Sagare A, Winkler EA, Zlokovic BV (2010) Protein S controls hypoxic/ischemic blood-brain barrier disruption through the TAM receptor Tyro3 and sphingosine 1-phosphate receptor. Blood 115:4963-4972.

Zuckerman V, Wolyniec K, Sionov RV, Haupt S, Haupt Y (2009) Tumour suppression by $\mathrm{p} 53$ : the importance of apoptosis and cellular senescence. J Pathol 219:3-15. 